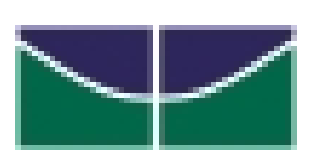

UNIVERSIDADE DE BRASÍLIA

Programa de Pós-Graduação em Administração - PPGA

Curso de Especialização em Gestão de Programas e Projetos Educacional

\title{
ANÁLISE DA EFICIÊNCIA E DA EFICÁCIA DA ARRECADAÇÃO DA CONTRIBUIÇÃO SOCIAL DO SALÁRIO-EDUCAÇÃO DIRETA VIA FNDE E OS IMPACTOS NA LEGISLAÇÃO
}

Iriovaldo Dias Antunes

Brasília-DF

2009 


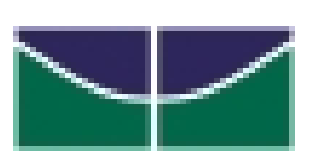

UNIVERSIDADE DE BRASÍLIA

Programa de Pós-Graduação em Administração - PPGA

Curso de Especialização em Gestão de Programas e Projetos Educacional

\title{
ANÁLISE DA EFICIÊNCIA E DA EFICÁCIA DA ARRECADAÇÃO DA CONTRIBUIÇÃO SOCIAL DO SALÁRIO-EDUCAÇÃO DIRETA VIA FNDE E OS IMPACTOS NA LEGISLAÇÃO
}

\author{
Autor: \\ Iriovaldo Dias Antunes \\ Orientador: \\ Professor Adalberto Domingos da Paz
}

Monografia do Curso de Especialização em Gestão de

Programas e Projetos Educacional, apresentado para o Programa de Pós-Graduação em Administração - PPGA, da Universidade de Brasília - UnB

Brasília-DF 


\section{$\psi$ \\ UNIVERSIDADE DE BRASÍLIA \\ Programa de Pós-Graduação em Administração - PPGA \\ Curso de Especialização em Gestão de Programas e Projetos Educacional}

FICHA DE AVALIAÇÃO DE MONOGRAFIA DE CURSO DE PÓS-GRADUAÇÃO LATO SENSU

Curso: Gestão de Programas e Projetos Educacionais - FNDE

Aluno: Iriovaldo Dias Antunes

Título da monografia: Análise da Eficiência e da Eficácia da Arrecadação da Contribuição Social do Salário-Educação Direta Via Fnde e os Impactos na Legislação

Atesto que avaliei a versão final da monografia acima indicada, entregue pelo autor ao Programa de Pós-Graduação em Administração (PPGA) em versão eletrônica, e que o meu parecer é o seguinte:

APROVAR a monografia com menção

REPROVAR a monografia com menção

Brasília, de de 2009.

Orientador: Professor Adalberto Domingos da Paz 


\section{DEDICATÓRIA}

Dedico a DEUS,

Condutor da minha difícil e longa caminhada, uma homenagem especial.

Não importa o chão que pisei, nem se foram tortuosos meus caminhos.

Não importa se ontem houve prantos ou, se caminhando apenas, gargalhei.

Nem importa se houve desencanto pelos caminhos que trilhei.

Não importa se colhi muitas rosas ou se muitos foram os espinhos.

Não importa se houve falhas e se os defeitos cobriram meus passos.

(Farias, 1997:218).

O mais importante é que, em todos este momentos, Você esteve comigo, me iluminando, me dando saúde, força, coragem e perseverança para continuar alcançando vitórias, que não são minhas e sim tuas.

Obrigado, meu bondoso Deus, Onipotente, onipresente, Soberano, Criador.

Criador a quem tudo devo e a tudo agradeço.

“Tudo posso naquele que me fortalece.”

(Flipenses, 4:13). 


\section{AGRADECIMENTOS}

“Ao meu Pai e minha Avó em memória”

À minha mãe, A minha esposa, Aos meus filhos: Bernadete Dias Antunes, Erotides Ferreira Cavalcante Antunes, Victor Hugo Cavalcante Antunes, Larissa Cavalcante Antunes e Isabelle Cavalcante Antunes.

Ao Fundo Nacional de Desenvolvimento da Educação, por ter concedido os recursos necessários ao financiamento deste curso.

A UnB - Universidade de Brasília, pela excelência no desempenho de sua missão de ensinar e na qualidade escolar de seus professores.

Ao Professor Adalberto Domingos da Paz, que confiou e me encorajou durante todo o desenvolvimento do curso e principalmente pela paciência e seriedade que ministrou as aulas e pela imediata disposição em me orientar na realização deste trabalho.

Ao Diretor Financeiro do FNDE, Antonio Correia Neto, pela disponibilidade de seu precioso tempo para conceder entrevista as quais foram fundamentais para o alcance dos objetivos deste trabalho.

A Coordenadora de Recursos Humanos do FNDE, Maria Goretti da Cunha, pela disposição e dispensa do período em que estive à frente do curso, destacamos ainda ao colega de trabalho, Patrício Barroso Pais, eficiente colaboradora; pois foi de excepcional importância à sua colaboração que muito subsidiou nosso trabalho, pois é conhecedor de um estudo avançado sobre o mesmo assunto o Salário-Educação, sem a colaboração da qual nosso trabalho seria bem mais difícil e sem dúvida bem mais demorada.

Aos meus colegas de trabalho, aos demais professores, colegas de classe, parentes e amigos, que de alguma forma contribuíram para o desenvolvimento deste trabalho. 
“A ética tem sempre a primazia sobre a técnica e os homens sobre as coisas”.

João Paulo II 


\section{RESUMO}

Este trabalho teve como objetivo analisar e aborda sobre a eficiência e a eficácia da arrecadação direta da contribuição social do Salário-Educação realizada pelo FNDE e os impactos na legislação, tema este, pouco estudado e discutido por outros pesquisadores e com literatura não escassa, mas pouco disponível. O tema é bastante significativo, imprescindível e indispensável para uma análise de políticas públicas visando Possíveis resoluções de problemas para o financiamento educacional para o nosso país, assunto este muito complexo, especialmente no que tange à educação infantil, aos ensinos; fundamental e médio, hoje denominada educação básica. Devemos considerar, também, a necessidade dos gestores públicos de realizarem gestões eficientes e eficazes melhorando a arrecadação dos impostos, uma vez que a sociedade não suporta mais aumento nessa área, devido a uma carga tributária de elevado suporte, considerada uma das maiores do mundo. Com uma grande diferença, porque mesmo nos países onde a carga tributária é grande, exemplo à Alemanha, a contrapartida, ou seja, o retorno em bem comum é gritantemente mais significante do que o Brasil, por exemplo, à qualidade, conservação e manutenção dos equipamentos públicos, da malha viária, dos portos, dos hospitais, sistema de ensino etc. Nesse contexto, o nosso trabalho procurou analisar os mecanismos da arrecadação adotados pelo FNDE, quais as premissas adversas, se a estrutura organizacional da Autarquia é adequada, a arrecadação é potencial e efetiva e qual o hiato dessa arrecadação, para saber sobre a eficiência e a eficácia da arrecadação direta da contribuição social do Salário-Educação pelo FNDE e os impactos na legislação.

Palavras-chave: finanças públicas, financiamento da Educação, Salário-Educação. 


\section{SUMÁRIO}

CAPÍTULO 1 - Introdução --- 09

1.1 Assunto -----

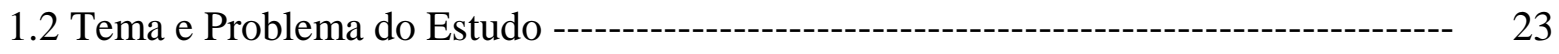

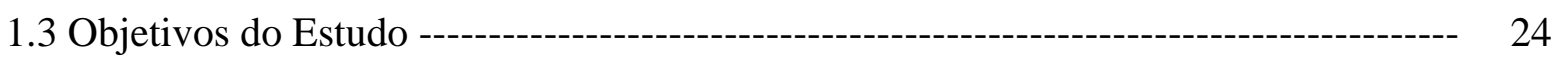

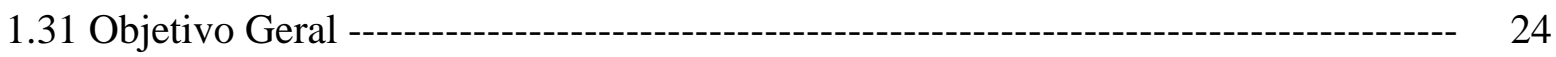

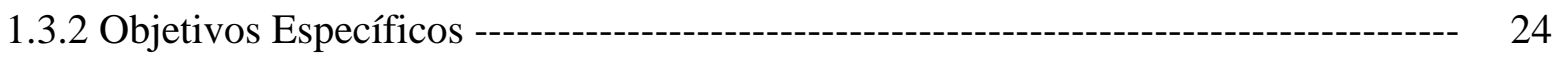

1.4 Justificativa e Relevância ---_-

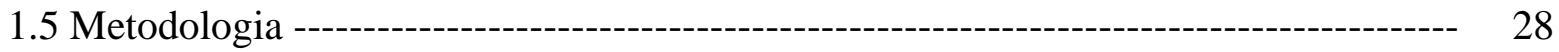

1.5.1 Coleta de Dados ---

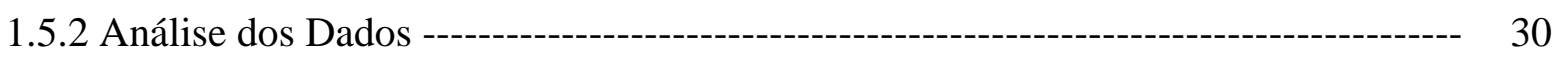

1.6 Organização do Trabalho -- 32

CAPÍTULO 2 - Referencial Teórico ---1.-- 33

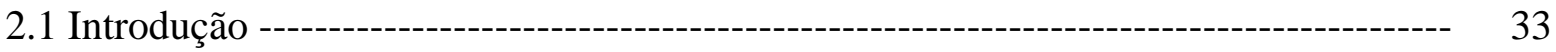

2.2 Conceitos Utilizados ---

\section{CAPÍTULO 3 - Estudo da Arrecadação Direta da Contribuição Social do}

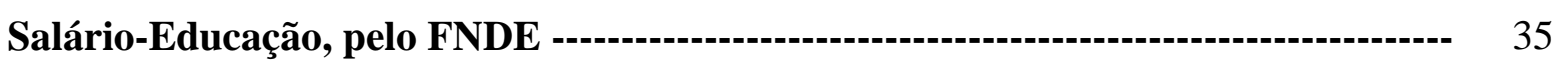

3.1 Introdução ---------- 35

3.2 Contextualização do Salário-Educação ----- 35

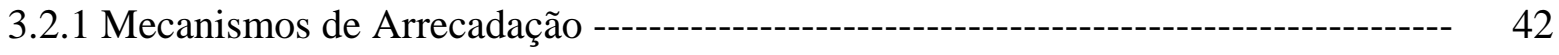

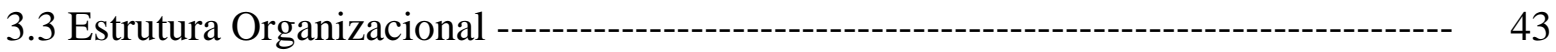

3.3.1 Coordenação-Geral de Arrecadação de Cobrança e de Inspeção -------------------- 44

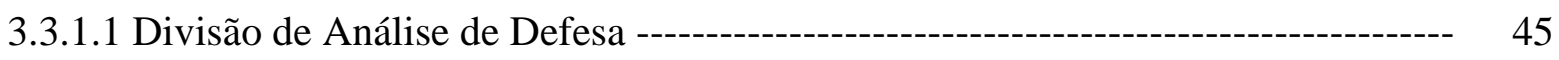

3.3.1.2 Coordenação de Arrecadação e Cobrança --------------------------------------- 46

3.3.1.3 Coordenação de Inspeção e Cadastro ---------------------------------------------- 46

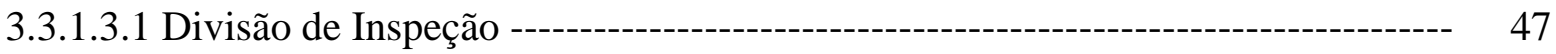

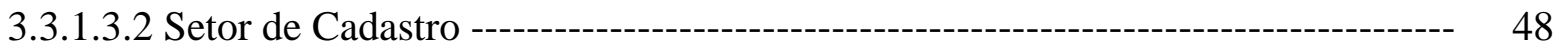

3.4. Evolução Histórica da Arrecadação no Período de 2000 a 2004 e janeiro a setembro de 2005 
CAPÍTULO 4 - Análise da Arrecadação Direta da Contribuição Social do Salário-Educação, pelo FNDE --------------------------------------------------------------- 59

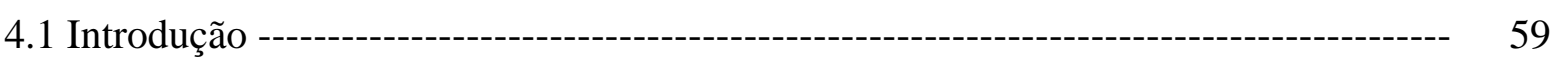

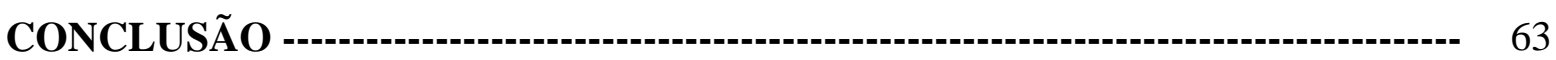

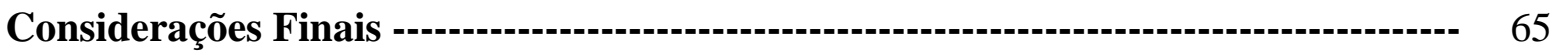

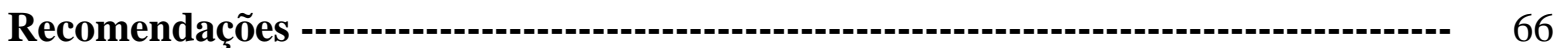

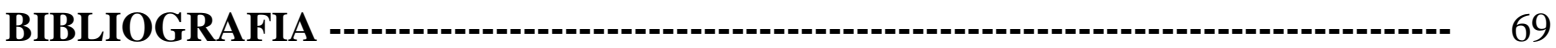

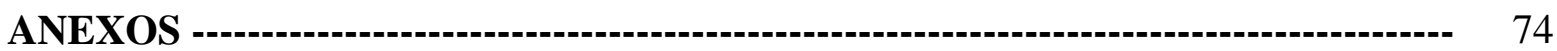




\section{CAPÍTULO I - INTRODUÇÃO}

Um dos aspectos de fundamental importância, talvez determinante, quando a discussão trata de Políticas Educacionais, diz respeito ao Financiamento do Setor Educação. Tanto no que se referem os mecanismos de arrecadação de recursos quanto à destinação e gestão destes.

De qualquer forma, o assunto não pode ser tratado desvinculado de um contexto maior onde se insere.

Em primeiro lugar é importante considerar que o financiamento do setor reflete, de forma imediata e mediata, as conseqüências das Políticas Públicas em nível nacional. De forma imediata, se considerarmos que as sucessivas crises econômicas, afetando os setores produtivos, tem como conseqüência a redução dos tributos que tenham incidência sobre os faturamentos das empresas ou mesmo as contribuições que incidam sobre as folhas de pagamento, implicando a redução da arrecadação desses "impostos", dos quais um determinado percentual será aplicado no setor educacional. De forma mediata, pelo fato de que, com o objetivo de conter as crimes econômico-financeiras, visando reduzir as taxas inflacionarias, os déficits públicos internos e externos etc, têm sido adotadas com freqüência medidas de controle salarial e até desempregos em massa. O que irá refletir na dificuldade da classe média em continuar pagando as escolas dos seus filhos, e, de forma mais drástica, junto àqueles que, mesmo sem o pagamento de mensalidade, não conseguem manter os filhos nas escolas, seja pela necessidade do ingresso destes no mundo do trabalho, seja pela impossibilidade de arcar com os custos indiretos da educação (transporte, alimentação, material didático, uniforme etc).

Em segundo lugar, sem com isto atribuir a este item um caráter secundário, o papel que o Estado destina à Educação e, conseqüentemente, os compromissos e/ou descompromissos que este mesmo "se atribui" são consoantes com a política de financiamento definidas para este setor.

Historicamente, com o processo de industrialização e conseqüente constituição de áreas urbanas, torna-se imperativa a necessidade de que os indivíduos tenham acesso à cultura letrada, além do que a passagem pela escola seria necessária à formação do cidadão. A escola assume, então, um papel de mediação entre o indivíduo e seu ingresso na sociedade industrial, tanto para ter condições de aprender os códigos utilizados por esta sociedade, quanto para "adquirir hábitos" condizentes com esta forma de organização social. 
Insistindo ainda nessa referência histórica, lembramos que a bandeira de escolarização universal e obrigatória é levantada quando da constituição da sociedade burguesa (sendo esta, naquele momento, a classe revolucionária, que toma o poder), portanto, sem querer atribuir ao Estado um caráter de neutralidade, o que implicaria imaginar um Estado pairando acima dos interesses de classem afirmamos que a escola, tal qual está constituída, é uma escola que se organiza de acordo com os valores e interesses da ordem burguesa. Em contrapartida, admitindo que numa sociedade capitalista as políticas públicas apresentam sempre uma natureza ambígua, em decorrência das contradições próprias desta organização social, constatamos que os destinatários destas políticas não são agentes passivos, numa sociedade em que as regras do jogo seriam ditadas pelos dominantes e cumpridas pelos dominados. Há, na realidade, uma disputa de interesses contraditórios, uma luta pela hegemonia, em que é possível observar avanços e recuos nessas políticas que por vezes traduzem as, conquistas dos grupos sociais, que, no presente, não são hegemônicos nas esferas de poder em que estas políticas são definidas.

É no bojo dessas disputas que poderíamos localizar a educação e a definição das políticas para seu financiamento. Um fato, porém, é inquestionável: uma sociedade que se pretende democrática, em que a defesa da liberdade de escolha e de oportunidades é bandeira, tem o dever de garantir à maioria da população o acesso a estas oportunidades.

As ambições do presente trabalho são limitadas, não pretendemos mais do que, utilizando uma bibliografia conhecida e reconhecida, apresentar uma trajetória, cujos contornos são bastante nítidos no sentido da privatização do setor educacional, via políticas de financiamento. Nesse aspecto, privilegiamos uma das fontes de recursos adicionais ao

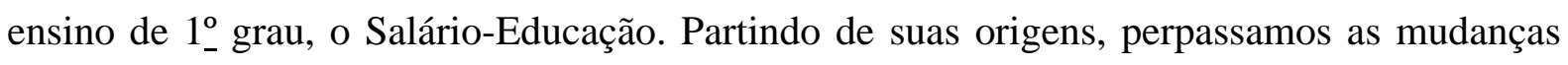
sofridas desde a sua instituição, chegando à promulgação da atual Constituição, onde apontamos para algumas propostas no que se refere à nova Lei de Diretrizes e Bases da Educação Nacional.

- Os compromissos do estado com a educação retratados nas constituições

Pontuamos como condições indispensáveis para democratizar a educação a definição de exclusividade do uso de recursos públicos no ensino oficial e a vinculação de recursos para o ensino através de preceito constitucional. Caberia fazer uma leitura dos compromissos assumidos pelo Estado brasileiro diante da Educação, resgatando algumas passagens das Constituições no período Republicano, além de referência à Lei de Diretrizes e Bases da Educação Nacional de 1961 e às Emendas Constitucionais $n_{-}^{0} 18$ —à Constituição de 1946 - e n_o 1 - à Constituição de 1967 —, estas últimas emendas aprovadas na vigência do 
regime militar. Para esta apresentação, utilizamos como referência (embora não exclusivamente) o trabalho de Luiz Antonio Cunha: A Educação nas Constituições Brasileiras: Análise e Propostas. Acrescentamos, por ser de interesse específico desse trabalho, a questão do financiamento do setor educação, a proposição da Emenda Constitucional $\mathrm{n}_{-}^{0} 24$ de dezembro de 1983, assim como, para completar o quadro dos compromissos constitucionais, a Constituição de 1988.

1891 — Primeira Constituição Republicana Embora não diga nada a respeito do direito à educação, proíbe o direito do voto aos analfabetos, o que só veio a ser modificado com a Constituição de 1988.

1934 — Quando da sua elaboração, os constituintes encontraram à disposição verdadeiros programas de educação, resultado de intenso debate entre as duas correntes de pensamento educacional, o tradicionalismo católico e o liberalismo. Em 1932, por exemplo, foi elaborado o Manifesto dos Pioneiros da Educação Nova. Determinava que "a educação é direito de todos e deve ser ministrada pela família e pelos poderes públicos".

Nesta Constituição não se previa o subsídio governamental às escolas particulares, embora definisse a seguinte concessão... "os estabelecimentos particulares de educação gratuita primária ou profissional, oficialmente considerados idôneos, serão isentos de qualquer tributo".

1937 — Constituição outorgada por Getúlio Vargas, conhecida como "polaca", por conta de ter sido concebida de acordo com os ideais do estado fascista italiano, dizia: "A educação integral da prole é o primeiro dever e o direito natural dos pais. O Estado não será estranho a esse dever, colaborando de maneira principal ou subsidiária, para facilitar sua execução ou suprir as deficiências e lacunas da educação particular".

Embora não houvesse menção explícita a subsídio governamental ao setor privado, os setores públicos eram apresentados como coadjuvantes ao ensino privado.

Não definia o percentual do Orçamento da União, dos Estados e Municípios a ser destinado à Educação.

1946 — Promulgada num regime liberal-democrático.

Definia: "O ensino dos diferentes ramos será ministrado pelos poderes públicos, e são livre à iniciativa particular, respeitadas as leis que o regulem".

Não trazia referência alguma a subsídio ao ensino privado, embora um artigo situado fora do capítulo Educação e Cultura recomendasse a "colaboração" dos poderes públicos com as igrejas e cultos religiosos, notadamente no setor educacional, além de definir que as empresas com mais de cem empregados eram obrigadas a manter o ensino primário 
para os empregados e seus filhos (art. 178, inciso II) - a vigência efetiva desse dispositivo só se dará com a promulgação da lei 4440, de outubro de 1964, que instituiu o SalárioEducação.

Essa Constituição restabelecia a vinculação de receitas para Educação prevista na Constituição de 1934. Determinava uma vinculação entre a receita e os gastos do governo Federal, do Distrito Federal, dos governos estaduais e municipais com a educação, devendo o primeiro aplicar $10 \%$ da receita dos impostos e os demais $20 \%$.

A Lei $n_{-}^{o}$ 4024/61 — Lei de Diretrizes e Bases da Educação Nacional, prevista pela Constituição de 1946, só foi promulgada em 1961, após intenso debate cuja polarização se deu entre os defensores do ensino público e gratuito e os defensores dos interesses privados, com a vitória destes, visto o fato desta lei não destacar o dever do Estado com a Educação, dividindo-o com a iniciativa privada, ao definir, por exemplo, no artigo $3_{-}^{\circ}$ que "O direito à educação é assegurado:

I — Pela obrigação do poder público e pela liberdade da iniciativa particular de ministrarem o ensino em todos os graus, na foma da lei em vigor;

II - Pela obrigação do Estado de fornecer recursos indispensáveis para que a família e, na falta desta, os demais membros da sociedade se desobriguem dos encargos da educação, quando provada a insuficiência de meios, de modo que sejam asseguradas iguais oportunidades a todos".

No que se refere à vinculação de recursos, definia que "A União aplicará, anualmente, na manutenção e desenvolvimento do ensino, 12\%, no mínimo, de sua receita de impostos, e os Estados, Distrito Federal e os Municípios, 20\% no mínimo" (art. 92).

Emenda Constitucional no 18/1965 — Emenda à Constituição de 1946, definiu a reformulação do sistema Tributário Nacional. Reforçou bastante o subsídio governamental ao ensino privado, já que vedava à União, aos estados e aos municípios cobrarem impostos sobre o patrimônio, a renda ou serviços de partidos políticos (os quais, neste momento, já haviam sido extintos pelo AI-2, e não haviam surgido ainda a ARENA e o MDB) e de instituições de educação e de assistência social.

1967 — Constituição formulada sob a vigência do regime militar, instaurado em 1964.

Retirou a vinculação de receitas à educação, ao contrário do que rezava tanto a Constituição de 1946, quanto a Lei de Diretrizes e Bases - 4024/61, o que levou a um sensível declínio na destinação de recursos para a educação. 
Institucionalizou, pela primeira vez em termos Constitucionais, o subsídio público ao setor privado, ao definir no Artigo 168, parágrafo segundo, que a iniciativa particular "merecerá o amparo técnico e financeiro dos Poderes Públicos, inclusive bolsas de estudos".

Emenda Constitucional n_. 1/1969 — Emenda à Constituição de 1967. Definia que "a educação é direito de todos e dever do Estado" e mantinha como na Constituição de 1967 o subsídio à iniciativa privada.

Impunha a vinculação orçamentária prefixada de 20\% para os municípios, apenas. O que, no contexto da Reforma Tributária de 1965, significava quase nada.

A restauração da vinculação de recursos só se dará em 1983, com a aprovação pelo Congresso Nacional da Emenda Constitucional $n_{-}^{0} 24$.

Emenda Constitucional $n_{-}^{\circ} 24$ - De autoria do Senador João Calmon e aprovada pelo Congresso Nacional em dezembro de 1983. foi regulamentada pela Lei $n_{-}^{\circ} 7.348$, de 24 de julho de 1985.

Restabelecia a vinculação de recursos resultantes da receita de impostos e que deverão ser aplicados na Educação. Definindo que a União deveria aplicar nunca menos que $13 \%$ e os estados, distrito federal e municípios, nunca menos que $25 \%$. Tais percentuais deveriam incidir sobre a receita própria e as transferências recebidas por força de mandamentos constitucionais, excluindo-se para esse fim as contribuições ou "tributos que não propriamente ditos", (lei $n_{-}^{o} 7.348 / 85$, art. 5_), sobretudo o Fundo de Investimento Social (FINSOCIAL) e o Salário-Educação.

Define como despesas de manutenção o desenvolvimento do ensino regular ou supletivo de todos os níveis, desde que as atividades estejam abrangidas pela legislação de Diretrizes e Bases da Educação Nacional e sejam supervisionadas pelos sistemas de ensino.

Em, 1988 - Promulgada em 5 de outubro de 1988. Da atual Constituição caberia destacar que, pela primeira vez, define-se constitucionalmente a "gratuidade do ensino público nos estabelecimentos oficiais", sem delimitar a gratuidade a um determinado nível.

Quanto ao vínculo dos recursos, reiterou o princípio vigente, estabelecido pela Emenda Calmon, aumentando entretanto o percentual a ser aplicado pela União, de 13\% para $18 \%$, a fim de minimizaras perdas das receitas federais, em decorrência de modificação no Sistema Tributário, diz que: "A União aplicará, anualmente, nunca menos de dezoito, e os Estados, o Distrito Federal e os Municípios vinte e cinco por cento, no mínimo, da receita resultante de impostos, compreendida a proveniente de transferir, na manutenção e desenvolvimento do ensino. 
No que se refere à destinação dos recursos públicos, define que eles serão dirigidos às escolas públicas, "podendo ser dirigidas a escolas comunitárias, confessionais ou filantrópicas, definidas em lei". Aqui cabe a observação feita por Jacques Velloso de que, no nível superior, "por lei, nenhuma instituição particular pode ter finalidade lucrativa; todas as faculdades e universidades do país são entidades filantrópicas".

Se a leitura de artigos constitucionais, desvinculada dos textos em que estão inseridos, pode fazer com que incorramos no risco de conclusões apressadas, por outro lado acreditamos que ela pode nos dar a medida da ambigüidade dos compromissos assumidos pelo Estado com a Educação. Visto que ora são ratificadas as intenções de compromisso, onde os princípios básicos estão declarados (com exceção da Constituição de 1981), ora a responsabilidade é dividida com o setor privado, seja explicitamente, como observamos na Constituição de 1937, na qual o Estado é apresentado como coadjuvante do setor privado, seja através de mecanismos que permitem o desvio de verbas através de bolsas de estudos ou subsídios àquele setor.

No Brasil, a oferta de vagas nas escolas públicas se deu muito mais em conseqüência das pressões realizadas por demandas reprimidas na sociedade, do que por um planejamento do Estado no sentido de atender as necessidades do desenvolvimento da economia interna ou com vistas a uma Política Nacional de Educação. Assim, a existência de fato do ensino público e gratuito, nos demais níveis que não somente no lo $_{-}$grau, pode ser apresentado mais como resultado da resistência e da luta de segmentos sociais, como estudantes, professores e trabalhadores, ao longo da nossa história, em defesa da escola pública e gratuita, do que como uma prática respaldada por garantias Constitucionais, já que somente com a promulgação em 5 de outubro de 1988 da atual Constituição a gratuidade do ensino é garantida nos estabelecimentos oficiais, conforme define o inciso IV do artigo 206. Embora a mesma Constituição, mais adiante (inciso n art. 208), vá definir que a gratuidade nos demais níveis se dará de forma progressiva, enquanto extensão ao cumprimento da obrigatoriedade ao nível de $1_{-}^{\mathrm{o}}$. grau. Não sendo objetivo deste trabalho tecer uma análise das conquistas e derrotas retratadas na atual Constituição, cabe entretanto o comentário de que a discussão de uma Política Nacional de Educação, sem que se considerem os diversos níveis de ensino, de forma orgânica, articulada, interdependente, será uma discussão capenga, visada, na qual não se considerará por exemplo o nível, ou os níveis, em que se dá a formação dos profissionais que responderão pela formação dos níveis antecedentes.

- Sálário-Educação: contribuição social 
Contribuição patronal criada com a finalidade de suplementar os recursos públicos destinados à manutenção e ao desenvolvimento do ensino, se constituindo numa fonte adicional ao ensino fundamental público. O objetivo quando da sua criação era o de eliminar o analfabetismo no país.Tem sua origem na Constituição de 1946, quando é definido, no artigo 178, inciso II, que as empresas com mais de cem empregados eram obrigadas a "manter o ensino para seus servidores e filhos destes".

É interessante observar que esta prática vinha sendo adotada em outros países. Conforme relata Ana Lúcia Jensen, a XVIII Conferência Internacional da Instrução Pública, realizada em Genebra no ano de 1955, discutiu o tema "Financiamento da Educação". Como resultado da discussão, na qual 55 países estiveram presentes, 23 deles relataram que "o financiamento de educação pelas empresas era feito sob forma de contribuição voluntária ou de encargo compulsório, proporcional ao montante dos investimentos efetuados ou a folha de salários das empresas"

No Brasil, a vigência daquele dispositivo Constitucional só se tomou efetiva com a criação por lei (lei 4440, de 27 de outubro de 1964) da contribuição obrigatória mensal — o Salário-Educação - devida pelas empresas vinculadas à Previdência Social. Esta lei adotou o percentual de $2 \%$ sobre o salário mínimo, a ser recolhido pelas empresas em relação a cada empregado, independente do estado civil e do número de filhos.

Poucos meses depois, a Lei 4863, de 29 de janeiro de 1965, regulamentada pelo Decreto 57902, de 08 de março de 1965, reformulou o percentual e a base do cálculo. Esta passou a ser o valor total da folha de salário recolhido pelas empresas, e o percentual fixado foi de $1,4 \%$. Por este decreto:

— 50\% seriam destinados a crédito do Fundo Estadual de Ensino Primário, para aplicação no próprio Estado

— 50\% seriam vinculados ao Fundo Nacional do Ensino Primário, para aplicação pela União em todo território Nacional (pretendia-se fazer uma distribuição mais justa aos estados mais pobres da União).

Empresas com mais de cem empregados poderiam deixar de contribuir se tivessem ensino primário próprio ou distribuíssem bolsas de estudos aos empregados ou seus filhos, mediante convênios firmados com escolas privadas.

A legislação sobre o Salário-Educação sofreu, ao longo dos anos, alterações em várias de suas disposições, ora alterando a base de cálculos e percentuais, ora reformulando as isenções e o sistema de bolsas. Vale ressaltar que o montante e a distribuição das verbas 
resultantes do Salário-Educação sofreram mudanças importantes dez anos depois de sua criação.

A reformulação sofrida pelo ensino fundamental, com a promulgação da lei 5692/71, ampliando a escolaridade obrigatória de 4 para 8 anos, além de instituir p supletivo como uma nova modalidade de ensino, impôs a necessidade de mais recursos para o ensino de $\mathrm{l}_{-}^{0}$ grau. Através do Decreto-lei 1422, de outubro de 1975, regulamentado em dezembro de 1975 pelo Decreto 79624, artigo II, a alíquota de l ,4\% foi elevada para 2,5\% sobre a folha de pagamento, ao mesmo tempo que reduziu para 1/3 a quota federal e aumentou a quota estadual para 2/3 da arrecadação via IAPAS (o que aumentou os recursos da quota estadual, aumentando entretanto a concentração dos recursos nos estados mais ricos).

Um aspecto de fundamental importância a ser observado neste decreto é o fato de ampliar ainda mais as possibilidades de isenção de recolhimento por parte das empresas, já que as escolas que elas mantivessem não precisavam ser destinadas apenas a seus empregados ou filhos, mas a "quaisquer adultos ou crianças", no ensino regular ou supletivo.

Com o objetivo de obter um maior controle sobre os recursos do SalárioEducação, estando à frente do então Ministério da Educação e Cultura — MEC — o general Rubem Ludwig, através do Decreto 87.043, de março de 1982, o Salário-Educação sofre novas reformulações.

De acordo com o artigo $9_{-}^{\circ}$, as seguintes medidas foram adotadas:

- O programa de bolsas passava a desenvolver-se mediante recolhimento pelas empresas ao Fundo Nacional de Desenvolvimento Econômico — FNDE, órgão do MEC responsável pela arrecadação dos recursos do Salário-Educação — do valor mensal devido para aquisição de vagas na rede particular.

- O programa de bolsas, antes destinado apenas a empregados e seus filhos, passava a abranger "quaisquer adultos ou crianças".

Foi a partir deste decreto, quando se difundiram as expresso s "alunos de comunidade" e " Sistema de Manutenção de Ensino - SME", que se estabeleceram mecanismos que carrearam um enorme volume de recursos do Salário-Educação para a rede privada de ensino.

Com a vitória, na maioria dos estados da federação, dos governadores eleitos por "partidos de oposição" ao governo federal, a política do Salário-Educação, formulada em tempos em que o governo exercia uma influência/autoridade maior sobre os estados, mostrava-se "incompatível" com o novo quadro político. Associavam-se a isto as pressões dos governadores eleitos, a fim de descentralizar os recursos para os orçamentos estaduais. 
Em 1983, o MEC iniciou estudos para modificar o SME, decidindo municipalizar suas despesas da quota federal. A nova política para o Salário-Educação, foi definida pelo Decreto 88.374, de julho de 1983, sendo ministra da educação a Dra. Esther de Figueiredo Ferraz, apresentando os seguintes argumentos para adoção do decreto: "conter as fraudes que acabaram por ser detectadas pelas delegacias do MEC e pelo FNDE" "conter o crescente esvaziamento dos recursos destinados ao ensino publico de $\mathrm{l}_{-}^{0}$ grau" "redirecionar o fluxo do Salário-Educação, fazendo-o voltar ao seu leito natural".

Este decreto trazia três importantes alterações:

- concedia respaldo legal para o estabelecimento de pontes diretas entre os governos federal e municipais, determinando que 25\% dos recursos do FNDE se destinassem ao apoio de programas municipais ou intermunicipais de desenvolvimento do ensino do $1_{-}^{\circ}$. grau.

- em contrapartida às intervenções brancas (nos Estados), a nova política atendia aos pleitos dos governadores estaduais no sentido de sua intermediação local para concessão da bolsa de estudo do SME, já que passava a ser responsabilidade das Secretarias Estaduais de Educação a aquisição de vagas nas escolas privadas para os "alunos da comunidade" e permitia a concessão de bolsas para as crianças da rede pública, o que era vedado para legislação anterior.

- limitava as indenizações aos filhos de empregados entre 7 a 14 anos. Antes a indenização era para todos os filhos menores de idade.

Estas medidas, embora tímidas no sentido de conter a privatização, geraram grande reação por parte dos empresários da educação. Mas de qualquer forma, o principal aspecto deste decreto foi o estabelecimento de uma ponte direta entre o governo federal e os governos municipais, ferindo um dos princípios da federação e tendo como intenção passar por cima da autoridade dos governos estaduais.

Mecanismo de distribuição dos recursos

A Política de aplicação do Salário-Educação é estabelecida no plano federal; suas bases são fixadas em lei federal, e sua regulamentação é definida pelo Executivo da União, a quem compete recolher boa parcela de seus recursos e repassar parte de sua receita aos estados.

Isto posto, caberia conhecermos/identificarmos os tortuosos caminhos que têm percorrido os recursos, cuja lei de criação — Lei 4440/64 — definiu que estes deveriam ser aplicados no ensino básico obrigatório, em conseqüência, em benefícios do cidadão. 
O Salário-Educação enquanto uma contribuição social, portanto pelo caráter público de que se reveste, em princípio, deveria ter seus recursos destinados exclusivamente ao ensino público. Todavia, o que podemos observar em 25 anos de sua existência, é que progressivamente seus recursos foram sendo desviados para as escolas particulares, em detrimento da expansão de ofertas na rede pública (estadual) de ensino.

Jacques Velloso vai apontar que, desde a sua instituição, o Salário-Educação apresentou dimensões privatizantes:

A primeira pelo fato do Estado se eximir de oferecer ensino primário público e gratuito para todos, delegando parcialmente essa responsabilidade às empresas com mais de cem empregados.

A segunda por conceder isenções às empresas que distribuíssem bolsas de estudos a seus empregados e filhos, mediante convênios firmados com escolas particulares.

Estas medidas apresentavam como conseqüência, a médio e longo prazos, o vazamento de recursos para a rede privada, em detrimento da expansão do ensino público. Somavam-se a estas formas de esvaziamento as precárias condições em que se dava a fiscalização dos recolhimentos devidos pelas empresas que não estavam isentas do SalárioEducação. Segundo Velloso, em fins dos anos 60, a sonegação do salário-educação implicou que cerca de 500 mil novas vagas deixaram de ser criadas no ensino primário.

Mais tarde, em virtude da utilização dos estudos do autor pelo MEC, a sonegação viria a sofrer reduções, embora ainda continuasse até os anos 80 , mediante artifícios vários, como o de trabalhadores de fato incluídos nas folhas de pagamento das empresas, mas que "vêm sendo irregularmente caracterizados como temporários" (VELLOSO E SILVA, 1983).

Ainda de acordo com Velloso, constatamos que a receita total do SalárioEducação segue duas trajetórias distintas:

A primeira, onde os recursos são divididos entre a União e os Estados (até meados de 70, divididos em partes iguais: $50 \%$ ficavam com o MEC e 50\% retomavam aos estados de origem; a partir de 1975, os percentuais das quotas federal e estadual foram alterados).

O fato dos recursos dessa trajetória estar sob responsabilidade dos governos federal e estadual não significa que eles tenham sido aplicados prioritariamente na manutenção e desenvolvimento do ensino público. Neves apresenta os seguintes números:

Em 1987 "... cerca de 60\% dos recursos do Salário-Educação são alocados no Sistema de Manutenção de Ensino...”. 
"Dos 40\% dos recursos destinados à rede oficial, uma parcela é ainda reorientada pelo Estado para programas de ajuda à rede particular, tanto ao nível federal, quanto ao nível estadual, sob as mais diversas justificativas e modalidades".

A segunda é a trajetória dos recursos das empresas isentas do recolhimento do Salário-Educação (ou por terem escolas próprias, ou por firmarem convênios com escolas particulares). A sistemática de aplicação dos recursos nessa trajetória sofreu sucessivas modificações ao longo dos anos, num processo de crescente privatização. Os mecanismos de distribuição de bolsas de estudos e indenizações de despesas com escolarização em estabelecimentos privados pelo Decreto 1422/75 constituíram o que mais tarde veio a ser conhecido como Sistema de Manutenção de Ensino - SME. Através desses mecanismos, estimula-se o crescimento dos subsídios carreados para os negócios da educação, diminuindo ainda mais as verbas da escola pública.

O conjunto dos recursos do SME faz parte da receita total do Salário-Educação, mas não é contabilizado na quota federal nem na estadual. Portanto não integra os orçamentos do Ministério da Educação e Cultura - MEC - nem nas Secretarias Estaduais de Educação. O público só tem, em princípio, conhecimento dos recursos que seguem a primeira trajetória.

Neves vai mostrar que, no período de 1976-78, enquanto o número de empresas que recolhiam aos cofres oficiais aumentava em 29,6\%, no mesmo período, o número de empresas que empregavam seus recursos na manutenção de ensino próprio, na concessão de bolsas de estudos e em indenização crescia em 163\%. No início dos anos oitenta, acelera-se o declínio das taxas de crescimento econômico do país, que já se manifestava na segunda metade da década de 70. Instala-se a recessão, e conseqüentemente observamos o aumento do desemprego, a diminuição dos salários, assim como a redução do lucro das empresas.

Paralelamente cai a arrecadação tributária em todo o país, atingindo drasticamente a receita dos estados e municípios, acarretando deterioração ainda maior do ensino público. A arrecadação do Salário-Educação, através do Instituto de Administração da Previdência e Assistência Social — IAPAS —, baixa paulatinamente, sendo que, em 5 anos, cai para metade do seu valor real em 1980.

Surpreendentemente, nessa conjuntura, a receita dos recursos da trajetória do Sistema de Manutenção do Ensino, cresce ao invés de diminuir, visto que, conforme dados apresentados por Velloso, em 1983 estes recursos correspondiam a quase o triplo de 1980.

É nesse contexto que estavam previstas eleições diretas para os governos estaduais e, "naturalmente", com a previsão de possíveis vitórias da oposição. 
A fim de se fortalecer e participar do jogo das eleições, o governo federal adota uma série de medidas com o objetivo de robustecer suas finanças, as quais vinham sofrendo os efeitos da recessão instalada no país.

A intermediação do governo federal, através do MEC, nos negócios do Sistema de Manutenção do Ensino, poderia render-lhe alguns frutos políticos no plano estadual. Até então, embora patrocinado pelo Estado, o SME desenvolvia-se sem a participação do governo federal, ou seja, o MEC, não tinha controle do número de empresas que faziam a opção de aplicar os recursos do Salário-Educação no SME, tampouco do número de escolas envolvidas nesse Sistema. Conseqüentemente, os recursos que deveriam ficar retidos no Fundo Nacional de Desenvolvimento da Educação — FNDE (órgão vinculado ao MEC responsável por administrar as verbas do Salário-Educação), por força do mecanismo denominado "diferença de bolsas de estudo", eram mínimos.

Com o Decreto 87.043, de março de 1982, oficializa-se a participação do MEC enquanto intermediário na aplicação dos recursos do SME, ao mesmo tempo incentivando as empresas privadas a ampliarem suas aplicações no Sistema. A partir desse decreto, a receita do SME cresceu de forma tal que o ensino privado não conseguiu absorvê-la integralmente, o que fez com que as finanças do FNDE sofressem um aumento significativo.

O resultado das eleições de 1982 alterou a correlação de forças no país, sendo que em 22 estados da ¡federação foram eleitos governadores cujos discursos de campanha tinham em comum uma sistemática oposição ao governo federal.

Os novos governadores são empossados em 1983, numa conjuntura em que a recessão continua aumentando progressivamente; o Produto Interno Bruto — PIB apresenta um crescimento negativo de 3,2\%; a arrecadação do Salário-Educação começa a cair, tanto via IAPAS quanto recursos que seguem a trajetória do SME.

Por um lado manifestam-se os interesses e as pressões dos governos estaduais no sentido de descentralizar os recursos, oriundos das arrecadações tributárias para os orçamentos estaduais e, por outro, o interesse do governo federal em minar a autoridade desses governadores e estabelecer relações com os municípios, o que poderia ser rentável nas próximas eleições.

É nesse contexto que o Salário-Educação vai sofrer alterações nos mecanismos de aplicação dos seus recursos, através do decreto 88.374, de junho de 1983, o qual, fundamentalmente, vai conceder respaldo legal para o estabelecimento de pontes diretas entre o governo federal e os municípios. 
De acordo com Jacques Velloso, entre 1982 e 1984, a conexão municipal do MEC no $1_{-}^{\mathrm{o}}$. Grau aumentou suas aplicações em 325\%.

Efetivamente, nenhuma das modificações que sofreu o Salário-Educação, desde que foi instituído, alterou significativa ou estruturalmente seu caráter privatizante, visto que os seguintes aspectos continuaram inalterados:

- o fator trabalho é o que sofre oneração, já que a incidência se dá sobre a folha de pagamento das empresas e não sobre o seu faturamento;

- a distribuição dos recursos entre a União, os Estados e Municípios, deveria ser devidamente regulamentada de forma a minimizar a utilização de recursos conforme interesses eleitoreiros e a impedir que os recursos sejam aplicados em "sistemas de ensino" que não o público-estatal;

- as isenções concedidas, o que permite a aplicação de recursos do SME, se não forem eliminadas na sua totalidade, deverão ocorrer conforme cumprimento de critérios definidos em legislação específica, que estabelecia, por exemplo, a obrigação de prestar contas publicamente, no que diz respeito à utilização dos recursos.

Considerando-se que a elaboração de uma Carta Constitucional, numa sociedade em que interesses contraditórios estão em disputa, não podemos esperar que esta mesma Constituição apresente uma coerência interna, em que os interesses de um ou de outro grupo sejam integralmente vitoriosos. Por outro lado, a vitória de propostas de um determinado grupo, traduzidas em determinados preceitos constitucionais, não significa que estes serão cumpridos de forma tranqüila.

E no bojo dessas contradições que, se, por um lado, os defensores do ensino público estatal, quando da elaboração da Constituição de 1988, conseguiram aprovar que o Salário-Educação seja caracterizado como uma fonte adicional de financiamento do "ensino fundamental público" (até então, a legislação não discriminava a obrigatoriedade dos recursos serem aplicados no ensino público), por outro, o texto constitucional continua permitindo que as empresas deduzam do recolhimento do Salário-Educação "a aplicação realizada com o ensino fundamental de seus empregados e dependentes".

De acordo com o artigo 205 da Constituição Federal: “A educação, direito de todos e dever do Estado e da família, será promovida e incentivada com a colaboração da sociedade visando ao pleno desenvolvimento da pessoa, seu preparo para o exercício da cidadania e sua qualificação para o trabalho” ………………... No entanto, um dos maiores problemas que dificultam a aplicação plena desse artigo da Constituição, é sem dúvida, como garantir recursos financeiros suficientes para o financiamento da educação. 
No que se refere à ação pública pela educação, a LDB promulgada em 1996, atribuiu à União, aos Estados, ao Distrito Federal e aos Municípios a responsabilidade pela manutenção e expansão do ensino sem esquecer da estrutura de financiamento para tal. Essa estrutura de financiamento da educação é composta, em sua maior parte, de recursos provenientes de fontes do aparato fiscal, ou seja, recursos da vinculação de impostos. A outra parte, de acordo com Jorge Abrahão Castro (2001, p.) (texto gentilmente cedido pelo Colega e Colaborador Patricio Barroso Pais), “uma parcela considerável provém das contribuições sociais, principalmente, das contribuições originalmente destinadas ao financiamento da seguridade social e das contribuições criadas exclusivamente para a educação que é o Salário-Educação, e outras fontes relacionadas a operações de crédito”.

O Salário-Educação é uma contribuição social prevista no artigo 212, parágrafo $5^{\circ}$ da Constituição Federal, que serve como fonte adicional de recursos do ensino público fundamental, permitindo às três estâncias do Governo investir em programas, projetos e ações que qualifiquem profissionais da educação e estimulem alunos a permanecerem em sala de aula. Essa contribuição é uma das principais fontes de recursos financeiros utilizadas para a execução de políticas voltadas para a melhoria do ensino público fundamental. Corresponde, cerca de $60 \%$ do total aplicado pelo governo federal. É cobrada de qualquer empresa individual ou sociedade que assume os riscos de atividade econômica, urbana ou rural, com fins lucrativos ou não, bem como das empresas e demais entidades públicas de economia mista ou privada, vinculadas à Seguridade Social.

A alíquota incidente corresponde a 2,5\% sobre o valor total das remunerações pagas ou creditadas pelas empresas a qualquer título, no mês, aos segurados empregados, ressalvadas as exceções legais (contratos temporários e contratos especiais). Parte da arrecadação do Salário-Educação é feita pelo FNDE e parte pelo INSS. De acordo com dados do Relatório de Atividades do FNDE/2003, ao todo, 17 mil empresas recolhem diretamente no FNDE e 2,5 milhões, via INSS. As empresas que recolhem no FNDE representam 50\% da arrecadação e são grandes grupos empresariais. De acordo com dados apresentados pela Coordenação-Geral de Arrecadação, de Cobrança e de Inspeção, do FNDE, em 2003, a arrecadação do salário-educação ficou em torno de R\$ 4 bilhões, sendo R\$ 1,9 bilhão pelo INSS e R\$ 2 bilhões pelo FNDE. Em 2004, a arrecadação total ficou em 4, 8 bilhões, sendo que mais uma vez a arrecadação direta pelo FNDE representou cerca de 50\% do total arrecadado, e os outros $50 \%$ pelo INSS ${ }^{1}$.

\footnotetext{
${ }^{1}$ Dados fornecidos pela Coordenação-Geral de Arrecadação, de Cobrança e de Inspeção - FNDE, para o Relatório de Atividades/2004.
} 
O grande desafio de hoje, tanto de estudiosos de administração como daqueles que exercem funções gerenciais, tem sido encontrar a melhor maneira de tornar as organizações eficientes, eficazes e efetivas, de modo a garantir a realização dos objetivos a que elas se destinam. No FNDE não é diferente. A Autarquia tem buscado minimizar os custos da organização, por meio da racionalização de processos de trabalho e de recursos, buscando evitar desperdícios, no intuito de tornar a administração mais eficiente e produtiva, visando sempre o aumento da arrecadação por meios mais eficazes em uma abrangência de inspeção “in-loco" mais presente, visando maiores resultados financeiros.

Tendo em vista que o Salário-Educação é uma fonte de recursos da educação, gerenciada pelo FNDE, torna-se importante verificar como está sendo a performance deste órgão em relação à arrecadação desses recursos.

Esse trabalho tem como objetivo maior verificar se o mecanismo adotado pelo FNDE para a arrecadação direta do Salário-Educação é eficiente e eficaz. Cabe ressaltar que não se pretende, neste trabalho, esgotar o assunto em análise, nem tampouco para a busca de novas alternativas. O que se propõe é examinar algumas questões relevantes que evidenciam a atuação do FNDE em relação à eficiência nesta missão de gerenciar a arrecadação dessa fonte de recursos e com isso contribuir para o debate sobre o assunto e conseqüentemente, melhorar a gestão pública dos recursos da sociedade.

\subsection{Assunto}

\section{Genérico: Finanças Públicas}

Específicos: Financiamento da Educação

Particularidade: Salário-Educação e seus contrastes

\subsection{Tema: SALÁRIO EDUCAÇÃO: ANÁLISE DA EFICIÊNCIA E DA EFICÁCIA DA ARRECADAÇÃO DIRETA PELO FNDE}

O Fundo Nacional de Desenvolvimento da Educação - FNDE é uma Autarquia vinculada ao Ministério da Educação - MEC, criada em 21 de novembro de 1968 e tem como missão prover recursos e executar ações para o desenvolvimento da educação básica pública além de promover a melhoria da qualidade do ensino em todo o país.

Dentre os principais desafios do FNDE está arrecadação do Salário-Educação uma das maiores fontes de recursos utilizadas para o financiamento da educação infantil, 
fundamental e médio em todo o território nacional, sendo que esses recursos são arrecadados em parte diretamente pelo FNDE e parte pelo INSS. Para tanto, busca-se maior eficiência e eficácia na performance desta área de arrecadação sem esquecer dos valores fundamentais que norteiam os trabalhos da Autarquia relacionados à transparência, a busca da cidadania, inclusão social e principalmente a excelência na gestão da coisa pública.

Nesta perspectiva, a escolha do tema acima proposto poderá contribuir para uma reflexão sobre a atuação de cada unidade relacionada com arrecadação direta da Contribuição Social do Salário-Educação pelo FNDE.

Dessa forma, que o problema de pesquisa está relacionado com a seguinte pergunta: O FNDE tem conseguido eficiência e eficácia na Arrecadação direta da Contribuição Social do Salário-Educação?

\subsection{Objetivos do Estudo}

\subsubsection{Objetivo Geral:}

O objetivo geral consiste em verificar a eficiência e a eficácia do FNDE, na arrecadação direta da Contribuição Social do Salário-Educação.

\subsubsection{Objetivos específicos:}

- Examinar o mecanismo de arrecadação adotado pelo FNDE;

- Identificar os incentivos adversos gerados pelo mecanismo de arrecadação;

- Verificar se o FNDE tem estrutura organizacional adequada para alcançar uma Arrecadação eficiente e eficaz.

- Verificar se existe diferença entre a arrecadação potencial e a efetiva;

- Conhecer o Hiato da arrecadação.

\subsection{Justificativa e Relevância}

A Justificativa e a relevância deste trabalho não poderiam deixar de iniciar-se pelas preocupações constantes na nossa Constituição Federal/1988, a qual cria o Estado Democrático e de Direito e ainda se preocupa em especificar a necessidade do preparo do cidadão para o exercício da cidadania, além de registrar a preocupação que o Estado deve ter com as questões sociais, e a necessidade de implementar ações voltadas para a realização de 
uma justiça social concreta, como forma indispensável para a realização da cidadania e da democracia. De acordo com Matias Pereira, (2003: p. ),

[...] em termos genéricos, pode-se afirmar que o Estado numa República, longe de ser o senhor dos cidadãos, é o protetor supremo de seus interesses materiais e morais. Sua existência não representa um risco para as pessoas, mas uma verdadeira garantia de suas liberdades. Dessa forma, República é o tipo de governo fundado na igualdade formal das pessoas, em que os detentores do poder político exercem-no em caráter eletivo, representativo (de regra), transitório e com responsabilidade. Deve-se observar que, enquanto federação é forma de Estado, República é forma de governo.

No entanto, como descreve Matias Pereira, “O Estado, para sobreviver, necessita dos meios indispensáveis ao atendimento da sua organização e do cumprimento de suas finalidades, ou seja, para sustentar-se e realizar seus objetivos, precisa de receitas, sem as quais não podem existir”. Para a realização de seus objetivos, busca na sociedade, por meio da política tributária, os recursos necessários para o atendimento das suas funções.

Nenhuma economia moderna funciona sem a presença do Estado. Não se pode deixar de registrar a importância da presença deste, nas atividades onde o mercado não atua de forma eficiente, gerando as “falhas de mercado”. A educação, é exemplo claro de falha de mercado, onde ocorre a “assimetria de informações”, ou seja, os dois lados do mercado têm informações diferentes, fazendo com que o lado que têm menos informações saia perdendo. Além disso, existe a questão da equidade, que também, só ela já justificaria investimentos do governo na educação. A sociedade brasileira não suporta mais as desigualdades, gerando uma aversão aos graves problemas sociais. A desigualdade na distribuição de renda é gritante, ganhando apenas de alguns países da África, comprovadamente subdesenvolvidos.

Desta forma, pode-se passar a discussão sobre a preocupação, ao longo do tempo, em relação ao tema em debate. O financiamento da educação como área de estudos é bastante antigo e considerado por vários autores, indispensável para uma boa gestão das redes públicas de ensino. Para Jacques Velloso ${ }^{2}$ (2004, p.), as pesquisas na área ganharam fôlego nos países cientificamente centrais com o surgimento de um novo campo nos anos sessenta, o da economia da educação. A consolidação das pesquisas sobre o financiamento da educação, na literatura internacional, data desta década e da seguinte. A obra mais importante sobre 
financiamento da educação, considerada clássica neste campo, foi publicada há mais de quarenta anos atrás. Trata-se do texto de Benson³ ${ }^{3}$ o qual teve sua primeira edição em 1961, passando por sucessivas ampliações e revisões mais tarde que emoldurou a maior parte dos estudos de financiamento da educação por algumas décadas. O referido texto, transita por três visíveis perspectivas de análise. Uma a da receita, ou a da fonte, ou ainda a da captação dos recursos, sempre tentando responder a pergunta: como e onde obter as verbas.

Jacques Veloso ressalta, que nos anos 80, a redução na taxa de crescimento econômico da maioria das economias do cenário mundial, e a queda na renda per capita que assolou muitas nações em desenvolvimento, contribuíram para diversificar o foco original dos estudos sobre financiamento do ensino. Naquela década, a América Latina, o continente mais endividado do mundo, sofreu fortes pressões de agências financeiras internacionais e de países emprestadores de recursos, para reduzir os gastos públicos, privatizar empresas públicas e, nas atividades custeadas pelo Estado, encontrar novas fontes de recursos. Estudos indicam que as políticas de reestruturação (ou de ajuste) levadas a cabo nestes países, resultaram em efetiva redução nos investimentos públicos no ensino. ${ }^{4}$

Os recursos cada vez mais reduzidos para arcar com as despesas do ensino público no Brasil, e as necessidades de alavancar o sistema educacional para atender a demandar da economia por mão de obra qualificada, levaram os agentes públicos e pesquisadores a intensificar suas preocupações em relação à forma de obter verbas para financiar a educação. A questão ganhou força, também, no âmbito das finanças públicas. Assim, o assunto sobre a atuação do Estado na educação pública passou a ser tema privilegiado e a fazer parte integrante do projeto para uma sociedade democrática na qual quase tudo falta, principalmente, recursos para área da educação de todos, com graves conseqüências para as pessoas mais pobres dessa sociedade que não conseguem obter sucesso, apenas, contando com as forças do mercado.

Olhando por este prisma, o Estado deve agir para ser o agente preponderante das finanças públicas, cabendo a ele a responsabilidade de viabilizar o funcionamento dos serviços públicos essenciais demandados pela sociedade.

Para Matias Pereira (2003: p 37), para viabilizar o funcionamento desses serviços públicos, o Estado necessita de recursos financeiros, que são obtidos por meio de várias fontes. Dessa maneira, o custeio das necessidades públicas realiza-se por meio da

\footnotetext{
2 Jacques Velloso é Professor da Universidade de Brasília e Conselheiro do Conselho Nacional de Educação.

${ }^{3}$ Charles Benson, The Economics of Public Education, $2^{\mathrm{a}}$ ed., Houghton Miffin, Boston, 1970.

${ }^{4}$ Cf. Fernando Reimers, Deuda externa y financiamento de la educación - su impacto en Latinoamérica, UNESCO, Santiago do Chile, 1990.
} 
transferência de parcelas dos recursos dos indivíduos e das empresas para o governo. Portanto, “o objeto propício das finanças públicas é o estudo da atividade fiscal, ou seja, aquela desempenhada pelos poderes públicos com o propósito de obter e aplicar recursos para o custeio dos serviços públicos”. (Idem: p. 38)

O estudo em foco se justifica, também, pela ótica da teoria do capital humano ${ }^{5}$, tendo em vista que várias pesquisas realizadas evidenciaram as externalidades positivas geradas para toda sociedade, a partir da educação que os indivíduos recebem. Nesta perspectiva, o trabalho de Telles (2004), revelou que os retornos da educação, podem ir muito além do âmbito individual através de um spillover para o restante da sociedade, logo, os retornos agregados do capital humano são maiores que os retornos individuais, fortalecendo a justificativa de investimentos públicos em educação. Os estudos mostraram, também, uma forte relação entre investimento em educação e crescimento econômico. Nesta ótica, o estudo realizado por Cláudio André Gondim Nogueira e outros (2000), sobre crescimento e capital humano, concluiu que os investimentos em capital humano têm sido muito importantes na determinação dos níveis de produtividade média dos estados brasileiros, inclusive promovendo ganhos de produtividade superiores aos gerados pelos investimentos em capital físico.

Ademais, constatou-se um elevado grau de desigualdade entre estados brasileiros mais ricos e os mais pobres no que diz respeito aos indicadores de educação e os seus PIBs per capita. Tais desigualdades afetam sobremaneira os rendimentos decorrentes dos investimentos em capital humano, beneficiando de forma mais preponderante os estados mais desenvolvidos, trazendo implicações muito importantes sobre as perspectivas de crescimento dos estados mais pobres no longo prazo, tendo em vista as más condições educacionais das populações desses estados.

O resultado dessa pesquisa nos leva a refletir sobre a questão do Brasil diante do processo de globalização da economia mundial, onde aqueles países cujas populações não estiverem preparação educacional suficiente, poderão comprometer o futuro de tais economias, uma vez que a estratégia utilizada será atrair trabalho barato e desqualificada. Dessa forma, será cada vez mais difícil elevar as taxas de crescimento da economia e promover o desenvolvimento, haja vista a concorrência acirrada pelo processo de globalização. Para enfrentar essa situação, é urgente que o país faça investimentos vultuosos

\footnotetext{
5 “O termo capital humano, de acordo com Sandroni (1999, p. 41), é o conjunto de investimentos destinados à formação educacional e profissional de determinada população. (...) O termo é utilizado também para designar as aptidões e habilidades pessoais que permitem ao indivíduo auferir uma renda. Esse capital deriva de aptidões naturais ou adquiridas no processo de aprendizagem”.
} 
em educação, principalmente, em educação básica, visando elevar sensivelmente os níveis de produtividade de seus trabalhadores, do contrário, será massacrado pelas economias desenvolvidas. O aumento de investimento em educação poderá resultar em maiores investimentos de capital humano e tecnologia, o que conduzirá, conseqüentemente, a um aumento do crescimento e da produtividade. Temos um exemplo claro no contexto mundial, por exemplo, os chamados “TIGRES ASIÁTICOS”, notadamente a Coréia do Sul, só se desenvolveram após enormes recursos financeiros voltados para a educação. Temos ainda muitos outros exemplos dentre outros a Espanha e Nova Zelândia.

A política da UNESCO para a década de 1990 teve força catalisadora para ajudar a estabelecer uma agenda mínima para as reformas educacionais que, em diferentes níveis de profundidade, foram implementadas em muitos países, inclusive no Brasil. Além disso, foi aprovado pelo Congresso Nacional, a Lei de Diretrizes e Bases da Educação Nacional, levando em conta o que foi estabelecido na Declaração Mundial de Educação para Todos, pelos países membros da UNESCO.

Durante a década de 90 o Brasil promoveu avanços significativos em relação à democratização da educação, em todos os níveis, aumentando consideravelmente o número de matrículas e de concluintes do ensino fundamental. No entanto, há muito que fazer. A demanda por crescentes níveis de escolarização ocorre juntamente com a necessidade de promover maior qualidade no ensino. Nisso reside o maior problema para os agentes da educação pública, pois o desafio impõe a necessidade de mais recursos.

No Brasil, não há como negar o peso da carga tributária existente sobre a sociedade, não restando opção para o poder público, se não a de ser competente para não deixar que haja perdas, buscando a eficiência e a eficácia na arrecadação dos impostos já existentes.

Nessa perspectiva é que se pretende justificar a relevância deste trabalho, com intuito de contribuir (indiretamente) na obtenção de mais recursos para atender às necessidades de financiamento da educação no Brasil, aumentando a eficiência e a eficácia na arrecadação dos recursos do Salário-Educação.

\subsection{Metodologia}

Este trabalho pretende expor a sistemática utilizada pelo FNDE para arrecadação da contribuição social do salário-educação, com a preocupação de conhecer melhor suas nuances. Por outro lado, pretende-se fazer uma análise dos mecanismos utilizados para a 
arrecadação, visando identificar os incentivos premissas adversas, examinar a estrutura organizacional, a tecnologia e os recursos humanos envolvidos no processo de arrecadação para posteriormente interpretar as informações na perspectiva de apresentar conclusões. Portanto, trata-se de uma pesquisa do tipo “descritiva” e “exploratória”.

\subsubsection{Coleta de dados}

O estudo será feito com base em dados primários que serão colhidos a partir de entrevistas realizadas com os responsáveis por cada área da Arrecadação direta da contribuição social do Salário-Educação e entrevista qualitativa com o Diretor Financeiro do FNDE sobre o tema. Os dados secundários serão obtidos em como livros, teses, dissertações, artigos, periódicos da Capes, Relatórios, legislação e buscas na Internet, entre outros, bem como estudos empíricos publicados sobre o tema em análise. Schindler (2003, p 223).

A realização de análise dos dados estatísticos exige que os dados primários sejam coletados de diversas fontes. Pra Yin (2001, p. 120), “a necessidade de utilizar várias fontes de evidências ultrapassa em muito a necessidade que se tem em outras estratégias de pesquisa, como em experimentos, levantamentos ou pesquisas históricas”.

A utilização de diversas fontes de dados primários permite, segundo Yin (2001, p.121), “[...] o desenvolvimento de linhas convergentes de investigação, um processo de triangulação”. Dessa forma, uma descoberta ou conclusão em um estudo de caso é muita mais convincente e acurada, se derivada de várias fontes distintas de dados, obedecendo a um estilo corroborativo de pesquisa.

Para a realização deste trabalho, optou-se pela coleta dados entrevistando os responsáveis por cada setor ligado à arrecadação do salário-educação, para obter os dados primários que não estão expressos em relatórios estruturados. Além disso, a observação também, foi constante, tendo em vista a minha atuação num desses setores.

A entrevista é uma fonte importante de dados e é muito utilizada em estudos de casos. Sua importância, de acordo com King (1995, p. 14), está ligada à alta flexibilidade do método, à possibilidade de ser usado em qualquer lugar e à capacidade de gerar dados em grande profundidade. A entrevista semi-estruturada pode ser definida, segundo Trivinõs (apud Zanoteli, 2001, p. 29) como “[...] aquela que parte de certos questionamentos básicos, apoiados em teorias e hipóteses, que interessam à pesquisa, e que, em seguida, oferecem amplo campo de interrogativas, fruto de novas hipóteses que vão surgindo à medida que se recebem as respostas do informante". Assim a entrevista semi-estruturada permite que o 
entrevistador e entrevistado interajam e que ambos sejam flexíveis em suas perguntas ou respostas, respectivamente.

O roteiro das entrevistas utilizado foi bastante amplo, possibilitando o entrevistado falar abertamente sobre tudo que ele achasse interessante sobre aquele setor o qual ele é o responsável. Abrindo-se espaço, também, para uma avaliação sobre o que ele pensa sobre a eficiência da arrecadação direta do salário-educação, como um todo.

O questionário foi do tipo fechado e as perguntas foram definidas de forma a obter respostas classificatórias, ou seja, que permitissem classificar numa escala percentual alguns dados para análise da eficiência e eficácia da arrecadação direta do salário-educação pelo FNDE.

Outra técnica utilizada para a coleta de dados foi à observação participante, desenvolvendo atividades em um dos setores analisados. Dessa forma, esse estudo será pautado em diversas técnicas complementares, visando uma melhor descrição do caso e também maior aprofundamento na pesquisa.

\subsubsection{Análise dos Dados}

De acordo com Yin (2001, p. 154), para uma análise de dados de alta qualidade é fundamental observar alguns aspectos: deixar claro que a análise esteve pautada em todas as evidências relevantes; a análise deve abranger todas as principais interpretações concorrentes; a análise deve se dedicar aos aspectos mais significativos do estudo de caso; e o pesquisador deve utilizar seu conhecimento prévio de especialista para analisar o estudo de caso.

Dessa forma, a análise dos dados coletados na realização do estudo deve ser uma análise de qualidade e objetiva, além de confiável. Para tanto, os dados deste trabalho foram analisados por meio de diversas técnicas de análise de dados, incluindo análise de conteúdo, técnica de triangulação e modelagem. Além disso, os dados coletados no questionário foram analisandos com o auxílio do Excel.

A análise de conteúdo, segundo Bardin (1997, p. 42), podem ser definida como:

[...] um conjunto de técnicas de análise das comunicações visando obter, por procedimentos, sistemáticos e objetivos de descrição do conteúdo das mensagens, indicadores (quantitativos ou não) que permitam a inferência de conhecimentos relativos às condições de produção/recepção (variáveis inferidas) destas mensagens. 
Para Bardin (idem, idem), fazem parte da análise de conteúdo “[...] todas as iniciativas que, a partir de um conjunto de técnicas parciais mas complementares, consistam na explicação e sistematização do conteúdo das mensagens e da expressão do conteúdo”.

Para Cooper; Schindler (2003, p.346), “análise de conteúdo mede o conteúdo semântico ou o aspecto o quê da mensagem”. Entre as vantagens da análise de conteúdo, para Schindler (idem, p. 347), estão: protege contra percepção seletiva do conteúdo; garante a aplicação rigorosa de critérios de confiabilidade e validade; e é respectiva à informatização.

Segundo Bardin (1977, p. 95), o processo de análise do conteúdo envolve três fases: pré-análise; exploração do material; e tratamento dos resultados, inferência e interpretação. A pré-análise é a fase de organização do material que. "corresponde a um período de intuições, mas tem por objetivo tornar operacional e sistematizar as idéias iniciais, de maneira a conduzir a um esquema preciso do desenvolvimento das operações sucessivas, num plano de análise” (idem, idem). Nesta fase são três dimensões que se deve considerar: escolha dos documentos que serão submetidos à análise; formulação das hipóteses e dos objetivos e elaboração de indicadores que fundamentem a interpretação final.

De acordo com Bardin (1977, p. 100), “[...] a exploração do material consiste essencialmente de operações de codificação, desconto ou enumeração, em função de regras previamente formuladas”. Por fim, o tratamento dos resultados obtidos e a interpretação, consistem em tratar os dados brutos de maneira a torná-los significativos e válidos. Segundo Bardin (1977, p. 101), “[...] depois de obtidos esses resultados o pesquisador pode propor inferências e adiantar interpretações a propósito dos objetivos previstos, ou que digam respeito a outras descobertas inesperadas”.

Nesse trabalho uma técnica que contribuiu para a análise dos dados foi a triangulação. Essa técnica, de acordo com Pozzebon; Freitas (1998, p. 164), permite “[...] dirigir nosso interesse aos processos e produtos centrados no sujeito: averiguando as percepções do sujeito, mediante entrevistas e questionários, e os comportamentos e ações do sujeito, na observação livre; aos elementos produzidos por meio do sujeito: documentos, especificações de sistemas, projetos, etc.; e aos processos e produtos originados do contexto sócio-econômico; mas voltado para estudos sociológicos”.

Por outro lado, o uso da modelagem também foi importante para a análise dos dados possibilitando recriar o contexto por meio dos dados colhidos a partir de percepções do pesquisador, dos respondentes e da transcrição de documentos. 


\subsection{Organização do Trabalho}

O trabalho será organizado em capítulos e seções, sendo que o capitulo I descreve o tema abordado, bem como a justificativa e relevância do trabalho, os objetivos: geral e específicos, além da metodologia e da organização do trabalho.

O capítulo II apresenta o embasamento teórico utilizado para a realização do trabalho e os conceitos utilizados.

O capítulo III trata do Estudo de Caso propriamente dito, o qual inicia-se com uma breve introdução, passando-se para a contextualização do Salário-Educação e pela estrutura organizacional a qual a arrecadação da contribuição social do salário-educação está inserida no FNDE, bem como a evolução histórica da arrecadação no período de 2000 a 2004, além dos mecanismos utilizados para essa arrecadação.

O capítulo IV aborda a análise da arrecadação direta da contribuição social do Salário-Educação, com uma breve introdução, os incentivos adversos, a arrecadação potencial x arrecadação efetiva e uma breve conclusão.

Depois vem a conclusão e as considerações finais, além da bibliografia e os anexos. 


\section{CAPITULO 2 - REFERENCIAL TEÓRICO}

\subsection{Introdução}

Não há como falar de eficiência e eficácia na arrecadação de tributos sem antes falar do papel do Estado na promoção do bem comum e como ele se contextualiza nesse processo.

A reforma do Estado que se iniciou em 1995 com o Plano Diretor do Brasil teve como preocupação principal a sua reconstrução para enfrentar os novos desafios da sociedade pós-industrial, no sentido de viabilizar o cumprimento dos contratos econômicos bem como assegurar os direitos sociais e a competitividade no novo cenário mundial. Ao contrário do que apresentava a proposta neoliberal, vários estudos evidenciam que o Estado continua sendo um instrumento indispensável para o desenvolvimento econômico, social e político em todo o mundo. Em especial no Brasil, como afirma Matias Pereira, (2002: p 1), “as idéias de reforma do Estado tem como referência os aspectos relacionados à necessidade de fortalecimento da democracia, retomada do desenvolvimento econômico e a redução das desigualdades na região”.

Com a nova definição do seu papel, o Estado passa a se adequar a uma nova função de “Estado Gerencial” que de acordo com Bresser Pereira (2001:30), “é um Estado democrático e eficiente que financia a fundo perdido os serviços sociais e a pesquisa científica e age como capacitador da competitividade das empresas privadas”.

Dessa forma, o Estado deve interferir nas atividades econômicas, política e social, por meio de diferentes mecanismos, visando atender aos anseios e aspirações da sociedade, no que se refere, não só a promoção do desenvolvimento econômico, redistribuição da renda, estabilização da economia, mas também, por meio da produção e fornecimentos de bens e serviços públicos. Para tanto, o Estado precisa dos recursos que são indispensáveis à realização dessa tarefa. Isso se dá por meio da transferência de parte dos recursos dos indivíduos e das empresas para o governo por meio da política de tributação.

É claro que todo Estado moderno não pode prescindir de uma burocracia moderna e competente. Uma burocracia eficiente capaz de assegurar a obtenção e o emprego dos meios materiais para a realização dos serviços públicos demandados pela sociedade.

Vale registrar, que à medida que cresce o nível de renda nos países industrializados, cresce, junto às necessidades da participação relativa do governo no sentido 
de promover as necessidades relacionadas ao bem-estar social, entre elas a educação e saúde, que cresce junto com a economia do país.

Por tanto, as organizações necessitam constantemente avaliar suas estruturas, visando adotar modelos para tornar essas organizações públicas mais eficientes e dinâmicas, para o alcance de seus objetivos. Nesse contexto, o FNDE está inserido, como todas as Autarquias do Governo Federal que vem sofrendo com o desmonte dos serviços públicos ao longo dos anos, mas que também tenta saltar dessa burocracia, enferrujada para a modernização dos seus serviços.

O problema das finanças públicas do governo brasileiro tem tomado posição cada vez mais prioritária na pauta das discussões da sociedade, sendo inclusive ponto chave no controle da inflação. Esse problema é evidente partindo dos dados relacionados ao déficit de caixa e o esgotamento da via de endividamento para suprir as necessidades de dispêndios. Somando ao fato que o período de inflação alta dos últimos anos tornou quase impossível os investimentos públicos que agora se fazem indispensáveis. É mister que o governo explorem da forma mais eficiente e produtiva a base tributária a ele designado por lei.

Todavia, as informações a respeito da eficiência e eficácia da Unidade responsável pela exploração da arrecadação da contribuição social do salário-educação são bastante limitadas, tendo a falta de disponibilidade de material teórico.

\subsection{Conceitos Utilizados}

- EFICIÊNCIA - é a qualidade de fazer com excelência, sem perdas ou desperdícios (de tempo, dinheiro ou energia). EFICIENTE é aquilo ou aquele que chega ao resultado, que produz o seu efeito específico, mas com qualidade, com competência, com nenhum ou com o mínimo de erros. O eficiente vai além do eficaz. A eficiência tem uma gradação: uma pessoa, máquina ou organização pode ser mais ou menos eficiente que outra. Uma secretária pode ser mais eficiente amanhã do que hoje. Um sistema de refrigeração pode ser mais eficiente que outro. Já a eficácia implica sim ou não: uma medicação, por exemplo, ou é eficaz ou não é.

- EFICÁCIA é atingir o objetivo proposto, cumprir, executar, operar, levar a cabo; é o poder de causar determinado efeito. EFICAZ então é o que realiza perfeitamente determinada tarefa ou função, que produz o resultado pretendido. 


\section{CAPÍTULO 3 - ESTUDO DA EFICIÊNCIA E DA EFICÁCIA DA ARRECADAÇÃO DIRETA DO SALÁRIO-EDUCAÇÃO, PELO FNDE.}

\subsection{Introdução}

O objetivo deste capítulo é contextualizar a Arrecadação direta da contribuição social do Salário-Educação, dentro da estrutura geral do FNDE. Pretende-se, portanto, expor a estrutura organizacional da qual compõem a arrecadação, suas atribuições, recursos humanos e mecanismos utilizados.

\subsection{Contextualização do Salário-Educação}

A contribuição social do Salário-Educação, como já foi definido na introdução deste trabalho, é uma contribuição social prevista no art. 212, parágrafo $5^{\circ}$ da Constituição Federal, foi criado para servir de fonte adicional de recursos para o financiamento do ensino fundamental público, que provém da contribuição social das empresas vinculadas à Seguridade Social, recolhido na forma da lei.

A contribuição surgiu devido à preocupação dos gestores públicos de suplementar os recursos destinados ao financiamento do então ensino primário, bem como de estabelecer a co-participação do segmento empresarial na obra educacional brasileira, várias iniciativas do Poder Público tiveram como enfoque primordial concretizar esse processo integrado de ação solidária, cujas formas e critérios de participação das empresas se constituíram objeto de inúmeros dispositivos legais disciplinadores, que culminaram na instituição e consolidação do Salário-Educação e do Sistema de Manutenção de Ensino de $1^{\circ}$ Grau - SME. Este último como alternativa de contribuição e financiamento do atual ensino fundamental.

O Salário-Educação foi instituído, inicialmente, pela Lei $n^{\circ}$ 4.440/64, regulamentada pelo Decreto n ${ }^{0}$ 55.551/65. Essa legislação estipulou que o Salário-Educação corresponderia ao custo do ensino primário dos empregados e filhos destes, calculado sob a forma de quota percentual, com base no salário-mínimo local e seria destinado a suplementar as despesas com a educação pública fundamental. Nesta primeira legislação a base de cálculo e a alíquota foram fixadas em $2 \%$ do salário-mínimo local, por empregado, mensalmente, e já estava determinado que o Salário-Educação seria estipulado pelo sistema de compensação do custo atuarial do ensino primário. 
Destaca-se que, no período de 1964 até 1975, dentro da vigência da Lei n $^{\circ}$ 4.440/64, havia competência supletiva aos estados-membros legislarem sobre a matéria, fixando e regulamentando o salário-educação juntamente com a União. Da alíquota fixada pela União, 50\% do total arrecadado seria repassado aos estados-membros, sendo que a União conservaria, na esfera federal, para aplicação nos programas e projetos educacionais a outra metade.

De 1964 a 1965, a União arrecadou com base na alíquota cheia de 2\% do saláriomínimo local, estipulada pela Lei $n^{\circ} 4.440 / 64$. Todavia, a partir da edição da Lei $n^{\circ} 4.863$, de 29 de novembro de 1965, regulamentada pelo Decreto n ${ }^{0}$ 57.902, de 2 de março de 1966, foi alterada a base de cálculo do Salário-Educação que passou a ser sobre a folha do salário-decontribuição da legislação previdenciária, ficando fixada a alíquota federal em 1,4\%, restando 0,6\% para instituição e regulamentação pelos estados-membros.

Até 1975, era arrecadado, simultaneamente à alíquota federal de 1,4\%, outra “parcela estadual” do salário-educação, também incidente sobre a mesma base de cálculo, até o máximo de 0,6 \%, nos estados-membros que disciplinaram a matéria.

Nesse período, constatou-se que, apesar de todos os esforços envidados pelos vários níveis de governo, a quantidade de vagas disponíveis para atendimento a todos os candidatos ao Ensino de $1^{\circ}$ grau, era insuficiente, além das manifestações de governos e entidades de classe, sobre a disparidade de alíquotas estaduais e seus critérios de cálculo, diferenças de forma de arrecadação e outras circunstâncias.

A instituição do Decreto-Lei $n^{0}$ 1.422/75, teve como objetivo revogar a competência supletiva dos estados-membros para legislarem sobre a matéria, atribuindo competência exclusiva à União, a fim de introduzir uma sistemática uniforme para o lançamento, arrecadação, fiscalização, controle e distribuição do salário-educação, fundindo as alíquotas federal e estaduais aplicadas, naquele momento, além de ajustar o valor do custo do ensino primário, pelo sistema de compensação do custo atuarial.

Com isso, a União buscou oferecer o nível básico de ensino em escolas privadas aos empregados e filhos destes, das empresas em geral, concebendo-se um sistema, denominado Sistema de Manutenção do Ensino de $1^{\circ}$ Grau. Dentro desse sistema, simultaneamente, se reduzia a pressão da demanda por vagas nas escolas públicas, e se estabelecia às empresas a co-participação na obra educacional brasileira.

Por esse motivo editou-se o Decreto-Lei $n^{0}$ 1.422, em 23 de outubro de 1975, regulamentado pelo Decreto $\mathrm{n}^{\circ}$ 76.923, em 23 de dezembro de 1975, mais tarde alterado pelo Decreto $n^{\circ}$ 87.043/82, que dispuseram sobre o salário-educação de forma unificada e sob a 
competência da União Federal, com alíquota única à base de 2,5\% sobre a folha do salário-decontribuição, de acordo com a legislação previdenciária, continuando, da mesma forma que na legislação passada, a ser estipulado pelo sistema de compensação do custo atuarial do ensino de $1^{\circ}$ grau.

O mesmo Decreto-Lei estabeleceu, assim, que a divisão do montante total da arrecadação seria em duas cotas, sendo 2/3 (dois terços) em favor dos governos dos estados, territórios ou Distrito Federal; e 1/3 (um terço) em favor do Fundo Nacional de Desenvolvimento da Educação - FNDE, autarquia do, então, Ministério da Educação e Cultura.

Observa-se, pois, que a alíquota inicialmente estabelecida, foi de 2,5\%, tomandose por base a soma da alíquota federal, de 1,4\%, mais o teto da alíquota estadual, de 0,6\%, e mais $0,5 \%$ de ajuste pelos cálculos demonstrativos do sistema de compensação do custo atuarial do ensino de $1^{\circ}$ grau, nos termos da Lei ${ }^{\circ} 4.440 / 64$, então vigente.

Para se entender melhor como seria esse sistema de compensação do custo atuarial do ensino de $1^{\circ}$ grau há que se discorrer um pouco sobre o Sistema de Manutenção do Ensino do $1^{\circ}$ grau - SME para verificar a forma que foi empreendida na realização dos cálculos e como se chegou à alíquota aplicada.

O SME possibilitava às empresas contribuintes substituir a obrigatoriedade da contribuição diretamente pela prestação do ensino às suas expensas, mediante: ensino próprio para seus empregados ou os filhos destes ou pelo sistema de compensação para quaisquer adultos ou crianças; ou pelo sistema de bolsas de estudo, mediante contrato com instituições de ensino particular; ou indenizando as despesas de auto preparação de seus empregados, com a comprovação de conclusão do $1^{\circ}$ grau, via exames supletivos; ou indenizando os empregados por seus filhos menores, mediante comprovante de freqüência, em estabelecimentos pagos; ou, ainda por um esquema misto, usando combinações das alternativas anteriores. Em todos estes casos, era recolhido apenas o valor líquido da contribuição após a dedução das despesas efetivadas.

Por um critério de isonomia entre os diversos participantes do sistema, foi fixado um valor mensal, que seria de 12 \% do valor de referência então vigente, para fins previdenciários.

Na Exposição de Motivos do Decreto-Lei $n^{\circ}$ 1.422/75 já se enfatizava a importância de se dar a este percentual uma certa flexibilidade, em virtude da necessidade de adaptação a fatores conjunturais supervenientes. 
Cabe lembrar, por oportuno, que havia uma série de fatores envolvidos na determinação do exato índice a ser aplicado: em primeiro lugar, a demanda reprimida por oportunidades de ensino, mais ampla do que o simples universo dos filhos dos empregados regularmente contratados pela empresa, pois a modalidade escola própria era, também, extensiva a outros membros da comunidade, o que levou à sua utilização, primordialmente, em locais onde não havia ensino de $1^{\circ}$ grau público (fazendas pertencentes às usinas de açúcar e álcool, locais onde se pratica a mineração, canteiros de obras de usinas hidrelétricas, etc.). Também os próprios empregados que não haviam concluído sua educação compuseram a clientela favorecida.

Iniciou-se, então, a tarefa de realização dos cálculos atuariais mencionados no diploma legal, pela estimativa do quantitativo de alunos a ser atingido pelo sistema, levando em conta o tempo de permanência de cada um (um ano para os adultos que se submeteriam ao Ensino Supletivo, oito anos para os alunos que iniciavam o curso em idade regular); agregado a esse dado, cumpria levar em consideração a taxa de crescimento demográfico, resultando, anualmente, em novos ingressos, antes que as primeiras turmas admitidas concluíssem o curso.

A base de cálculo, denominada salário-de-contribuição, correspondia à massa salarial da mão-de-obra formalmente empregada no Brasil. Já se dispunha, naquele momento, de um histórico do valor aproximado do conjunto dos salários auferidos pelos empregados das empresas no país, sendo necessário elaborar projeções de como este número evoluiria sob a influência dos diversos fatores que produzem impacto econômico.

Considerando a repartição do produto da arrecadação entre União e Unidades Federativas, a parcela remanescente em poder do FNDE, deveria ser suficiente para custear o sistema em vias de criação, de modo que o total cobrado das empresas deveria corresponder aproximadamente ao triplo do necessário para atendimento ao SME.

Após a construção de vários cenários, concluiu-se que a proposta de 2,1 \% expandida inicialmente pelo Sr. Ministro era por demais conservadora, existindo o risco de não ser possível operacionalizar o atendimento aos alunos com a quota federal, e assim se deu a opção pelo percentual de 2,5 \%.

A decisão mostrou-se acertada, haja vista que a mesma alíquota vem sendo aplicada deste 1975; a partir de 1996, iniciou-se a gradativa extinção do SME, hoje Sistema de Manutenção do Ensino Fundamental, em virtude dos efeitos do planejamento familiar: o crescimento numérico da população em idade escolar já não é tão vertiginoso, com a redução do número de filhos por mulher, permitindo a concentração dos esforços mais na qualidade do 
que na quantidade de vagas oferecidas. Atualmente, o número de alunos remanescentes nas modalidades originais é bastante reduzido, e os recursos são aplicados, além do SME, em programas e projetos voltados para a melhoria do ensino fundamental público a cargo do Ministério da Educação, tais como: Programa Nacional do Livro Didático, Programa Biblioteca na Escola, Programa Nacional Saúde do Escolar, Programa Transporte do Escolar, Programa Dinheiro Direto na Escola, na complementação da União ao FUNDEF, Projetos de Construção e Reformas de Escolas Públicas e em vários outros.

O Salário-Educação é recolhido junto ao Instituto Nacional do Seguro Social INSS, órgão co-responsável pela fiscalização da sua arrecadação, ou ao Fundo Nacional de Desenvolvimento da Educação-FNDE. A referida contribuição não tem caráter remuneratório na relação de emprego e não se vincula, para nenhum efeito, ao salário ou à remuneração percebida pelos empregados das empresas contribuintes. Ela é calculada com base na alíquota de 2,5\% sobre o total de remunerações pagas ou creditadas pelas empresas, a qualquer título, aos seus segurados empregados, assim definidos pela Lei $n^{0}$ 8.212/91.

Paralelamente à aprovação da Lei no 9.394 - Diretrizes e Bases da Educação Nacional-LDB, em 1996, foram tomadas medidas que influenciaram a aplicação de recursos destinados para a educação. A criação do Fundo de Manutenção e Desenvolvimento do Magistério, pela Lei $n^{\circ}$ 9.424/96, prevê a descentralização da aplicação destes recursos em nível de município e define como prioritária a aplicação dos mesmos no ensino fundamental. Dentro deste contexto se encontra a nova legislação que rege a aplicação dos recursos da Quota Estadual do Salário-Educação.

A Lei $\mathrm{n}^{\circ}$. 9.424/96 dispõe que a partir de janeiro de 1997, o montante de arrecadação do Salário-Educação, após a dedução de 1\% em favor do INSS, calculado sobre o valor por ele arrecadado, será distribuído pelo FNDE, observada a arrecadação realizada em cada Estado e no Distrito Federal, em Quotas, da seguinte forma:

I - Quota Federal, correspondente a um terço do montante de recursos que será destinada ao FNDE e aplicada ao financiamento de programas e projetos voltados para a Universalização do Ensino Fundamental de forma a propiciar a redução dos desníveis sócio-educacionais existentes entre Municípios, Estados, Distrito Federal e regiões brasileiras; e

II - Quota Estadual, correspondente a dois terços do montante dos recursos que será creditada mensal e automaticamente em favor das Secretarias de Educação dos Estados e do Distrito Federal para financiamento de programas, projetos e ações do Ensino Fundamental".

A Medida Provisória $n^{\circ}$ 1.565/97, em seu Artigo 2º remete aos Estados a responsabilidade de redistribuir aos Municípios os recursos da Quota Estadual do Salário- 
Educação. Através da Lei Estadual n ${ }^{0}$ 10.013, de 24 de junho de 1998, foram estabelecidos os critérios da redistribuição da Quota Estadual do Salário-Educação entre o Estado de São Paulo e seus Municípios e o Decreto Estadual $n^{\circ}$ 43.377/98 veio definir o mecanismo pelo qual a transferência destes recursos será realizada.

A aplicação dos recursos da Quota Estadual do Salário Educação-QESE pela Secretaria de Estado da Educação, para um determinado exercício, é vinculada ao "Plano de Aplicação de Recursos" que deve ser encaminhado ao Conselho Estadual de Educação, para aprovação, no exercício anterior. Os recursos da QESE estão previstos no orçamento da SEE, de acordo com valores estimados pelo FNDE que mantém o controle sistemático da arrecadação do Salário-Educação referente à Quota pertencente a cada Estado.

Pode-se dizer o Salário-Educação, foi definido como uma contribuição compulsória das empresas destinadas ao ensino público com vistas ao cumprimento do artigo 168, Inciso III da Constituição Federal de 1967, de acordo com Emenda Constitucional $n^{\circ}$ 1/67 e nos artigos 17847 e 48 da Lei n ${ }^{\circ}$ 5.692/71, que fixa as diretrizes e bases para o ensino de $1^{\circ}$ grau. Dessa forma, o Salário-Educação foi, posteriormente, incorporado pela Constituição seguinte, como parte do próprio dispositivo e preservada pela Constituição Federal de 1988. O Parágrafo $5^{\circ}$ do artigo 212 estabelece que:

“o ensino fundamental público terá como fonte adicional de financiamento a contribuição social do Salário-Educação, recolhida na forma da lei, pelas empresas que dela poderão deduzir a aplicação realizada no ensino fundamental de seus empregados e dependentes”

A EC nº 14 deu nova redação ao parágrafo $5^{\circ}$ do artigo 212, estabelecendo que “o ensino fundamental público terá como fonte adicional de financiamento a contribuição social do Salário-Educação, recolhidos pelas empresas na forma da lei” retirando das empresas a oportunidade de deduzirem a aplicação realizada no ensino fundamental dos empregados e dependentes, Interrompendo dessa forma, a oportunidades de utilização desses recursos pelas empresas nas escolas particulares.

A Lei de Diretrizes e Bases da Educação de 1996, em seu artigo 68, item III, também reafirma a existência do Salário-Educação, como uma das fontes de recursos públicos destinados à educação.

Um grande problema que acontecia até 1996, era os questionamentos das empresas acerca da constitucionalidade do Salário-Educação. Esse problema foi resolvido em 
1996 com a decisão do Supremo Tribunal Federal, conforme especifica o Parecer da Procuradoria Jurídica do FNDE:

[...] A referida contribuição se reveste de total legitimidade, ratificada na declaração de constitucionalidade da Lei nº. 9.424, de 24/12/96, pelo Supremo Tribunal Federal, ao julgar procedente a Ação Declaratória de Constitucionalidade $\mathrm{n}^{0}$ 3.0, por meio da decisão publicada no Diário Oficial da União de 13/12/99, aduzindo decisão do STF, no mesmo sentido, que considerou recepcionados pela Carta Magna de 1988, o Decreto-Lei no 1.422/75 e o Decreto nº 87.043/82, ao julgar em 17/10/2001, o Recurso Extraordinário nº 290/079-6, ratificando assim, a exigibilidade da cobrança da contribuição do Salário-Educação desde o seu nascedouro até o advento da Lei $n^{\circ}$ 9.424/96, inclusive no que diz respeito à fixação da alíquota em 2,5\% incidente sobre o total de remunerações pagas ou creditadas, a qualquer título, aos segurados empregados.

Essa decisão foi fundamental para a continuidade da cobrança dos processos daquelas empresas que haviam ajuizado ações na justiça contra pagamento da contribuição social do Salário-Educação.

Em 30/12/2003, foi publicada a Lei n ${ }^{0}$ 10.832/03 com a nova regulamentação para a contribuição social do salário-educação, alterando sua destinação e percentuais de distribuição da seguinte forma:

- $1 \%$ correspondente à taxa de administração devida ao INSS, incidente sobre a arrecadação a cargo daquela instituição;

- até 2004, deduzia-se do Salário-Educação o valor necessário à gestão do Sistema de Manutenção do Ensino - SME, encerrado em 31 de dezembro, por força do $\S 3^{\circ}$, art. 15, da Lei 9.424/96;

- quota federal destinada ao FNDE, correspondente a um terço do montante líquido dos recursos arrecadados;

- quota destinada a estados, Distrito Federal e municípios, cujo repasse ocorre mensalmente e automaticamente, conforme alíquota definida com base no número de alunos matriculados no ensino estadual e municipal.

Por causa do fim do SME em 2003, não havia mais motivo para as empresas permanecerem recolhendo diretamente ao FNDE, por esta razão, editou-se o Decreto $\mathrm{n}^{\circ} 4.943$, 
de 30/12/2003, definindo que todas as empresas, cujo total das remunerações pagas ou creditadas, a qualquer título aos segurados empregados, tenha atingido o valor mínimo de R\$ 2.400.000,00 (dois milhões e quatrocentos mil reais), na folha de pagamento do mês de dezembro de 2003, excluindo-se o décimo terceiro, seriam obrigadas a recolherem diretamente no FNDE. Esse Decreto elevou o potencial da arrecadação direta do SalárioEducação e contribuiu para a elevação da arrecadação no ano seguinte.

\subsubsection{Mecanismos}

Como já foi dito anteriormente a Contribuição Social do Salário-Educação é arrecadado por dois meios:

a) diretamente ao FNDE, utilizando o Comprovante de Arrecadação Direta (CAD), nos casos determinados no art. $6^{\circ}$ do Decreto $n^{\circ} 3.142 / 99$, com a redação dada pelo Decreto $n^{\circ}$ 4.943/2003;

b) ao INSS, por meio da Guia da Previdência Social (GPS), na rubrica “Outras Entidades” - Campo 9, na qual se inclui, entre outras contribuições, o Salário-Educação.

Até o final de 2003, havia o Sistema de Manutenção do Ensino Fundamental SME no âmbito no Âmbito do FNDE.

O SME é um Programa pelo qual a empresa, no exercício de direito adquirido anteriormente à Emenda Constitucional $n^{\circ}$ 14/96, propiciava o ensino fundamental aos empregados e seus dependentes.

Após a edição da Emenda Constitucional no 14, as novas empresas ou novos estabelecimentos de empresas já existentes que vinham a receber empregados responsáveis por alunos beneficiados podiam formalizar a sua opção pelo SME e passar a arrecadar a contribuição do Salário-Educação diretamente ao FNDE. Todavia era vedada a inclusão de novos alunos. Somente poderiam permanecer até o término do ensino fundamental os alunos que entraram até o mês dezembro de 1996, finalizando-se em 2003.

As empresas podiam participavam, de acordo com as seguintes modalidades:

a) Escola própria - era uma alternativa pela qual, mantendo estabelecimento de ensino à suas expensas, a empresa garantia ensino fundamental gratuito aos empregados e dependentes, deduzindo do recolhimento mensal referente à contribuição do SalárioEducação, o valor de R 21,00 (vinte e um reais), multiplicado pelo número de alunos beneficiados. 
b) Indenização de Alunos - Nesse caso, a empresa reembolsava aos empregados beneficiados a importância de 126,00 (cento e vinte e seis reais) por vaga correspondente ao semestre, e deduzia esse valor dos recolhimentos devidos do Salário-Educação ao FNDE.

c) Aquisição de Vagas - Essa alternativa proporcionava a empresa, com a intermediação do FNDE, adquirir vagas na rede particular de ensino para seus empregados e dependentes, deduzindo tais valores dos recolhidos do Salário-Educação. Por algum tempo, chegou a ser praticado a chamada DBE- Diferença de Bolsas de Estudo, ou seja, se a empresa gerava mais bolsas do que tinha de empregados, a diferença era distribuída para alunos da comunidade.

d) Esquema Misto - Nesse caso, a empresa podia optar por mais de uma modalidade, visando à educação fundamental dos empregados e dependentes, deduzindo os valores da arrecadação do Salário-Educação.

Para realização da Fiscalização do SME foi criado o Programa Integrado de Inspeção em Empresas e Escolas - PROINSPE, por meio da Resolução CD/FNDE $n^{\circ}$ 15, de 19.10.1993, e alterada pela Resolução CD/FNDE $\mathrm{n}^{\circ}$ 36, de 25.10.1995, tendo sua ação consolidada pelo Decreto ${ }^{0}$ 3.034, 27.04.1999, que aprovou a estrutura regimental do FNDE, colocando a seu cargo a fiscalização da regularidade da situação de empresas e escolas, em relação às contribuições devidas para o Salário-Educação, na forma que dispõe o Decreto 3.142, de 16.08.1999 e a Resolução CD/FNDE nº 19/2000.

\subsection{Estrutura Organizacional}

A arrecadação direta da contribuição Social do Salário-Educação, faz parte das atribuições da Diretoria Financeira do FNDE, compondo-se de uma Coordenação-Geral de Arrecadação, de Cobrança e de Inspeção, duas Coordenações uma de Inspeção e a outra de Arrecadação; e duas Divisões, conforme Organograma abaixo. Possui um total de 120 servidores sendo 50 deles pertencentes ao quadro permanente do FNDE e 70 servidores terceirizados.

Cabe dizer que, embora, não conste do Regimento Interno do FNDE, existem os seguintes setores: Apuração e Cobrança de Débito - SETAD; Parcelamento de Débito SEPAR e o Setor de Arrecadação - SECAR, os quais são as molas mestras da arrecadação do Salário-Educação, juntamente com as demais unidades. 


\section{Organograma baseado do Regimento Interno do FNDE}

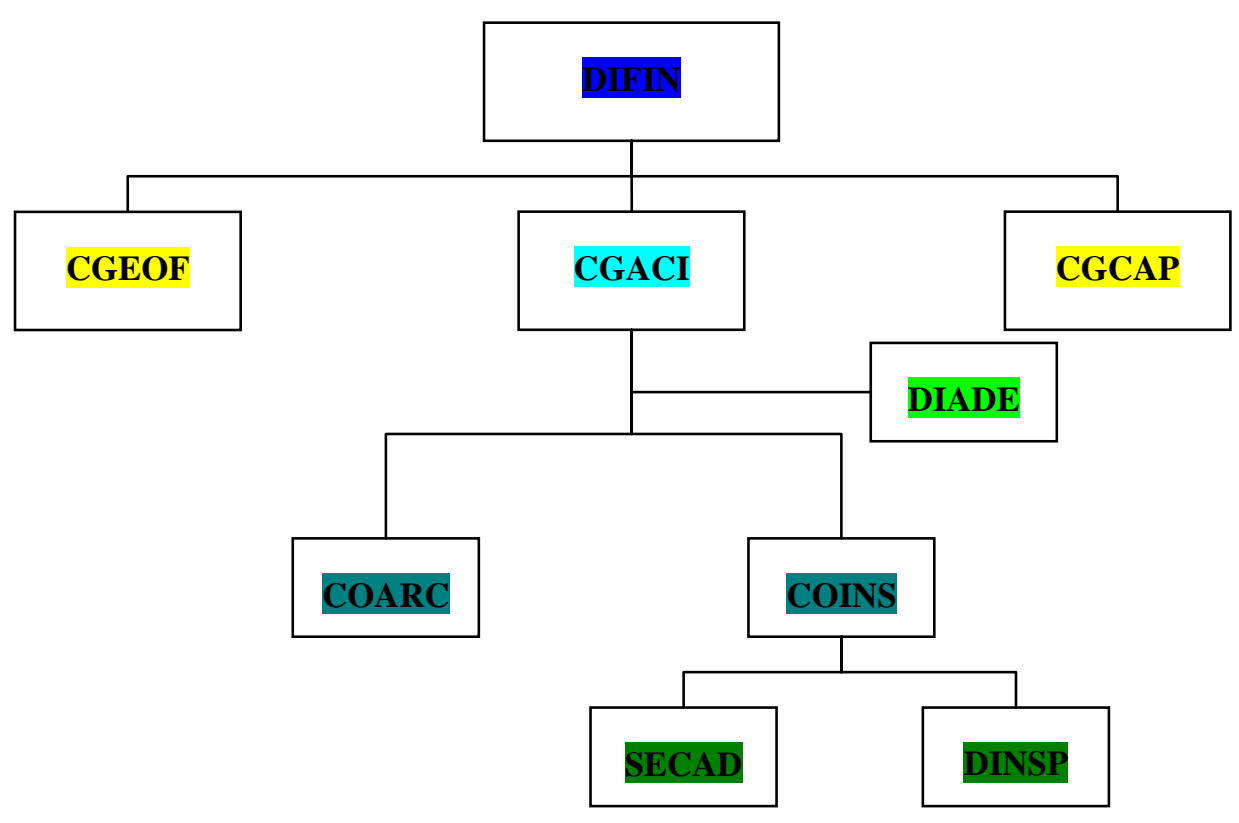

\subsubsection{Coordenação-Geral de Arrecadação de Cobrança e de Inspeção - CGACI}

À Coordenação-Geral de Arrecadação de Cobrança e de Inspeção - CGACI compete $^{6}$ planejar, coordenar, acompanhar e supervisionar a execução das atividades de arrecadação do salário-educação e, especificamente:

I elaborar estudos e propor ações que visem ao incremento da arrecadação do salário-educação;

II - elaborar e propor normas e manuais de orientação atinentes à arrecadação do salário-educação;

III - orientar e supervisionar as atividades relacionadas com a aplicação das contribuições relativas ao salário-educação pelas empresas optantes pela arrecadação direta;

IV - supervisionar os pagamentos aos estabelecimentos de ensino credenciados no SME;

V - elaborar e submeter à apreciação superior o plano de inspeção em empresas e escolas, e aprovar a indicação dos servidores que comporão a equipe de cada inspeção;

VI - supervisionar e coordenar as atividades de inspeção nas empresas e escolas, executadas por servidores da Autarquia, pelas Representações do MEC do Estado de São Paulo e do Rio de Janeiro e pelas Secretarias Estaduais de Educação; 
VII - notificar empresas e escolas devedoras e encaminhar, quando necessário, os respectivos processos à Procuradoria Federal do FNDE para execução da dívida;

VIII - submeter à autoridade competente parecer referente à baixa ou à retificação das notificações emitidas, ao deferimento ou ao indeferimento de defesas apresentadas pelas empresas e escolas notificadas;

IX - submeter À aprovação superior os pedidos de restituição de valores às empresas credoras junto ao FNDE, bem como os pedidos de parcelamento administrativo;

$\mathrm{X}$ - propor à Procuradoria Federal do FNDE rescisão de parcelamento de débitos das empresas não cumpridoras das condições estabelecidas no Termo de Confissão de Dívida firmado;

XI - propor a celebração de novos contratos com entidades externas e as alterações no contrato celebrado com o agente arrecadador; e

XII - prestar cooperação técnica aos agentes executores das ações relativas À arrecadação, à cobrança e ao SME, no que se refere a treinamento, aperfeiçoamento e outros aspectos da execução.

\subsubsection{Divisão de Análise de Defesa - DIADE}

Art. 44. À Divisão de Análise de Defesa compete:

I - analisar as defesas apresentadas pelas empresas e escolas, relacionadas às notificações de débito, e elaborar

parecer conclusivo para decisão da Presidência do FNDE;

II - acompanhar a publicação da legislação e de atos normativos pertinentes à arrecadação do salário-educação e ao

relacionamento com as escolas, e disseminar o seu conteúdo;

III - encaminhar os recursos administrativos ao Conselho Deliberativo do FNDE; e

IV - representar, no âmbito de sua competência, a Coordenação-Geral perante entidades públicas e privadas, bem

como perante as unidades da própria Autarquia, quando solicitado.

\footnotetext{
${ }^{6}$ Portaria no 3.511 , de 28 de outubro de 2004, que aprova o Regimento Interno do Fundo Nacional de Desenvolvimento da Educação - FNDE.
} 


\subsubsection{Coordenação de Arrecadação e Cobrança - COARC}

Art. 45. À Coordenação de Arrecadação e Cobrança compete:

I - divulgar às empresas as normas aplicáveis à arrecadação direta da contribuição do salário educação;

II - coordenar a distribuição dos documentos de arrecadação direta do salárioeducação;

III - acompanhar e controlar os recolhimentos efetuados pelas empresas optantes pela arrecadação direta;

IV - analisar pedidos de restituição de contribuições recolhidas indevidamente pelas empresas;

V - zelar pela integridade do banco de dados, analisando os movimentos bancários diários e eliminando eventuais inconsistências;

VI - analisar pedidos de parcelamento de débitos, bem como supervisionar os respectivos pagamentos, propondo, se necessário, a rescisão dos parcelamentos concedidos;

VII - efetuar demonstrativos financeiros por exercício das empresas optantes pela arrecadação direta do salário-educação,

analisar seus resultados e, quando constatadas inconsistências, adotar as

medidas cabíveis;

VIII - elaborar os quadros de atualização de débitos resultantes de demonstrativos financeiros, informações

provenientes do INSS, aferição indireta e deduções indevidas preparando as notificações correspondentes; e

IX - propor ações específicas de cobrança do salário-educação.

\subsubsection{3 - Coordenação de Inspeção e Cadastro - COINS}

Art. 46. À Coordenação de Inspeção e Cadastro compete:

I - propor ações específicas das inspeções do salário-educação a serem realizadas pelo FNDE, com vistas à operacionalização das ações de arrecadação e cobrança;

II - acompanhar, controlar e coordenar as atividades relacionadas às inspeções do salário-educação realizadas pelo FNDE, pelas Secretarias de Educação dos Estados e pelas Representações do MEC no Estado de São Paulo e Rio de Janeiro;

III - indicar os servidores para compor a equipe de cada inspeção; 
IV - emitir notificação para recolhimento de débito proveniente de inspeção para decisão da Coordenação-Geral;

V - coordenar e supervisionar a distribuição às empresas das normas referentes ao salário-educação, bem como dos formulários destinados à formalização da opção pela arrecadação direta e à indicação de alunos;

VI - coordenar e supervisionar a distribuição aos estabelecimentos de ensino das normas e formulários para credenciamento, para celebração dos contratos e para comprovação dos serviços prestados;

VII - orientar as empresas e os estabelecimentos de ensino quanto à aplicação das normas e ao preenchimento dos formulários;

VIII - supervisionar a atualização dos cadastros de empresas, alunos e escolas, controlando a integridade dos mesmos;

IX - sugerir a fixação de prazos para acolhimento de documentos relativos à opção de empresas e para credenciamento de estabelecimentos de ensino;

$\mathrm{X}$ - acompanhar e controlar a manutenção do benefício do SME e da gratuidade do ensino fundamental aos beneficiários; e

XI - praticar os atos referentes aos empenhos e pagamentos relativos aos serviços prestados pelos estabelecimentos de ensino credenciados no SME.

\subsection{Divisão de Inspeção - DINSP}

Art. 47. À Divisão de Inspeção compete:

I - elaborar plano e cronograma anual de inspeção em empresas e escolas;

II - avaliar a conveniência e oportunidade da realização das inspeções a serem realizadas nas empresas e escolas, obedecendo aos critérios fixados pela Coordenação-Geral;

III - comunicar formalmente aos parceiros do FNDE as atividades de inspeção;

IV - examinar, nas empresas, a documentação relativa à contribuição do salárioeducação e aos alunos beneficiários do SME;

V - fornecer dados à Coordenação de Inspeção e Cadastro para a emissão de notificação às empresas ou escolas em débito; e

VI - encaminhar à Coordenação de Arrecadação e Cobrança, para análise e providências, os Termos de Confissão de Dívida firmados pelas empresas inspecionadas; e

VII - propor anualmente, para o exercício seguinte, as metas das inspeções a serem realizadas. 


\subsection{Serviço de Cadastro - SECAD}

Art. 48. Ao Serviço de Cadastro compete:

I - distribuir às empresas as normas referentes ao salário-educação e os formulários destinados à formalização da opção pela arrecadação direta e à indicação de alunos;

II - proceder à distribuição aos estabelecimentos de ensino das normas e formulários para credenciamento, à celebração de contrato e à comprovação dos serviços prestados;

III - manter atualizados os cadastros informatizados de empresas, de alunos e de escolas, controlando a integridade das informações contidas no banco de dados; e

IV - emitir cobranças relacionadas a inconsistências ocorridas no cadastro de alunos.

\subsection{Evolução Histórica da Arrecadação do Salário-Educação no Período de 2000 a 2004 e Janeiro a Setembro de 2005.}

De acordo com a legislação vigente (Lei $n^{\circ}$ 9.766/98 e Decreto $n^{0}$ 3.142/99) a arrecadação do Salário-Educação, realizada diretamente pelo FNDE, ocorre nos casos das empresas optantes pelo Sistema de Manutenção do Ensino Fundamental - SME .

$\checkmark$ No exercício de 2000, de acordo o Relatório de Atividades de 2000 (p. 43), inúmeras empresa que haviam suspendido os recolhimentos com autorização da justiça, ou mesmo com base na expectativa de que a referida contribuição fosse declarada inconstitucional, votaram a recolher. A mudança de atitude das empresas se deu em virtude do reconhecimento da constitucionalidade da contribuição social do Salário-Educação pelo Supremo Tribunal Federal, vindo a somar-se aos efeitos exógenos resultantes da expansão do número de empregos formais e crescimento da massa salarial.

Além desse fato, o que influenciou a desvinculação do Salário-Educação da base de cálculo do Fundo de Estabilização Fiscal - FEF, correspondendo a 20\% do total arrecadado, conforme art. 76, $\S 2^{\circ}$ da Emenda Constitucional $n^{\circ}$ 27/2000.

Esses fatores contribuíram para que no ano de 2000, houvesse um incremento na arrecadação de 18,28\% comparado com o valor bruto arrecadado em 1999, sendo que a arrecadação direta representou um acréscimo de $13,71 \%$. Do total da arrecadação, R \$1,43 bilhão foi realizada diretamente por meio do FNDE, e 1,35 bilhão por intermédio do INSS, conforme mostra a Tabela 01 . 
TABELA 01

ARRECADAÇÃO BRUTA DO SALÁRIO-EDUCAÇÃO NO ANO DE 2000

\begin{tabular}{|c|c|c|c|}
\hline \multicolumn{3}{|c|}{ ARRECADAÇÃO } & \multirow{3}{*}{$\begin{array}{c}\text { TOTAL DA } \\
\text { ARRECADAÇÃO }\end{array}$} \\
\hline MÊS & DIRETA & ARRECADAÇÃO & \\
\hline & PELO FNDE & PELO INSS & \\
\hline JAN & 116.827.971,32 & 161.648.373,19 & 278.476.344,51 \\
\hline FEV & 114.484.783,07 & 102.594.484,31 & 217.079.267,38 \\
\hline MAR & 108.157.665,61 & $91.400 .000,00$ & 199.557.666,61 \\
\hline ABR & $106.949 .964,27$ & 97.998.779,37 & 204.948.743,64 \\
\hline MAI & $107.810 .125,42$ & $109.000 .000,00$ & 216.810.125,42 \\
\hline JUN & 108.946.915,82 & $105.000 .000,00$ & 213.946.915,82 \\
\hline JUL & $102.053 .469,63$ & $110.000 .000,00$ & $212.053 .469,63$ \\
\hline AGO & 122.561.128,97 & $112.000 .000,00$ & 234.561,128,97 \\
\hline SET & 109.140.220,31 & $120.000 .000,00$ & 229.140.220,31 \\
\hline OUT & 108.113.783,34 & $120.000 .000,00$ & 228.113.783,34 \\
\hline NOV & 109.448.111,69 & $115.000 .000,00$ & $224.448 .111,69$ \\
\hline DEZ & 217.114.211,83 & $115.000 .000,00$ & $332.114 .211,83$ \\
\hline TOTAL & 1.431.608.351,28 & 1.351.672.457,50 & 2.791.249.988,15 \\
\hline
\end{tabular}

Fonte:FNDE/DIROF 
No exercício de 2001, por força do reconhecimento da constitucionalidade do recolhimento da contribuição social do Salário-Educação pelo Supremo Tribunal Federal, que influenciou também, no recebimento de algumas contribuições que se encontravam suspensas ou em atraso, houve um incremento de, aproximadamente, $12 \%$ em relação à arrecadação do ano de 2000, o que correspondeu uma diferença de R\$ 332 milhões, sendo que a arrecadação direta pelo FNDE cresceu 14,14\% em relação ao ano de 2000. Veja tabela 02.

TABELA 02

ARRECADAÇÃO BRUTA DO SALÁRIO-EDUCAÇÃO NO ANO DE 2001

\begin{tabular}{|c|c|c|c|}
\hline \multirow{3}{*}{ MÊS } & \multicolumn{3}{|l|}{ ARRECADAÇÃO } \\
\hline & DIRETA & ARRECADAÇÃO & TOTAL DA \\
\hline & PELO FNDE & PELO INSS & ARRECADAÇÃO \\
\hline JAN & 129.130.836,22 & 170.899.990,28 & $300.030 .826,50$ \\
\hline FEV & 125.169.973,02 & $110.700 .000,00$ & $235.869 .973,02$ \\
\hline MAR & 120.701.345,92 & $120.700 .000,00$ & $241.401 .345,92$ \\
\hline ABR & 118.333.308,31 & $126.000 .000,00$ & $244.333 .308,31$ \\
\hline MAI & 125.249.710,00 & $111.000 .000,00$ & $236.249 .710,00$ \\
\hline JUN & 128.653.231,37 & $115.700 .000,00$ & 244.353.231,37 \\
\hline JUL & $120.555 .595,58$ & $125.700 .000,00$ & $246.255 .595,58$ \\
\hline AGO & 134.448.415,16 & $126.700 .000,00$ & 261.148.415,16 \\
\hline SET & 128.923.177,03 & $116.700 .000,00$ & 245.623.177,03 \\
\hline OUT & $124.598 .352,28$ & 118.700.000,00 & 243.298.352,28 \\
\hline NOV & 127.586.565,66 & $120.700 .000,00$ & $248.286 .565,66$ \\
\hline DEZ & $250.727 .863,71$ & $125.700 .000,00$ & $376.427 .863,71$ \\
\hline TOTAL & $1.634 .078 .373,26$ & $1.489 .199 .990,28$ & 3.123.278.363,54 \\
\hline
\end{tabular}

Fonte:FNDE/DIROF

No ano de 2002, a arrecadação continuou crescendo, resultando num acréscimo de 19,45\% na arrecadação direta, em relação ao ano de 2001. Esses dados estão representados na Tabela 03. 
TABELA 3

ARRECADAÇÃO BRUTA DO SALÁRIO-EDUCAÇÃO NO ANO DE 2002

\begin{tabular}{|c|c|c|c|}
\hline \multicolumn{4}{|c|}{ ARRECADAÇÃO } \\
\hline MÊS & DIRETA & ARRECADAÇÃO & TOTAL DA \\
\hline & PELO FNDE & PELO INSS & ARRECADAÇÃO \\
\hline JAN & 149.919.309,97 & 215.772.724,54 & $365.692 .034,51$ \\
\hline FEV & $145.271 .869,64$ & $115.800 .000,00$ & 261.071.869,64 \\
\hline MAR & 148.228.518,94 & $120.800 .000,00$ & 269.028.518,94 \\
\hline ABR & 159.816.357,54 & $125.900 .000,00$ & 285.716.357,54 \\
\hline MAI & 148.391.254,97 & $127.000 .000,00$ & 275.391.254,97 \\
\hline JUN & 137.461.332,90 & $131.000 .000,00$ & 268.461.332,90 \\
\hline JUL & 132.752.969,73 & $132.000 .000,00$ & 264.752.969,73 \\
\hline AGO & 184.078.081,33 & $136.300 .000,00$ & 320.378.081,33 \\
\hline SET & 150.151.354,61 & $139.100 .000,00$ & 289.251.354,61 \\
\hline OUT & 153.770.108,74 & $149.500 .000,00$ & $303.270 .108,74$ \\
\hline NOV & 151.835.255,66 & $156.700 .000,00$ & $308.535 .255,66$ \\
\hline DEZ & 290.178.795,95 & $159.000 .000,00$ & 449.178.795,95 \\
\hline TOTAL & 1.951.855.179,98 & 1.708.872.724,54 & 3.660.727.904,52 \\
\hline
\end{tabular}


Com relação ao exercício de 2003, a arrecadação bruta do Salário-Educação foi da ordem de R\$ 4 bilhões, sendo que houve um pequeno acréscimo na arrecadação direta pelo FNDE, em torno de 5\% em relação ao ano de 2002. Os dados estão representados na tabela 04.

TABELA 04

ARRECADAÇÃO BRUTA DO SALÁRIO-EDUCAÇÃO NO ANO DE 2003

\begin{tabular}{|c|c|c|c|}
\hline \multicolumn{5}{|c}{$\begin{array}{c}\text { ARRECADAÇÃO } \\
\text { MÊS }\end{array}$} & $\begin{array}{c}\text { DIRETA } \\
\text { PELO FNDE }\end{array}$ & PELO INSS & $\begin{array}{c}\text { TOTAL DA } \\
\text { ARRECADAÇÃO }\end{array}$ \\
\hline JAN & $\mathbf{1 6 5 . 5 9 2 . 6 5 9 , 2 5}$ & $247.873 .240,29$ & $\mathbf{4 1 3 . 4 6 5 . 8 9 9 , 5 4}$ \\
\hline FEV & $\mathbf{1 5 6 . 2 1 2 . 7 0 6 , 0 5}$ & $122.700 .000,00$ & $\mathbf{2 7 8 . 9 1 2 . 7 0 6 , 0 5}$ \\
\hline MAR & $\mathbf{1 5 2 . 0 2 9 . 6 6 8 , 7 0}$ & $141.000 .000,00$ & $\mathbf{2 9 3 . 0 2 9 . 6 6 8 , 7 0}$ \\
\hline ABR & $\mathbf{1 4 6 . 3 2 0 . 5 4 2 , 4 2}$ & $148.000 .000,00$ & $\mathbf{2 9 4 . 3 2 0 . 5 4 2 , 4 2}$ \\
\hline MAI & $\mathbf{1 4 6 . 4 7 3 . 8 4 6 , 5 8}$ & $152.000 .000,00$ & $\mathbf{2 9 8 . 4 7 3 . 8 4 6 , 5 8}$ \\
\hline JUN & $\mathbf{1 4 8 . 2 2 9 . 5 1 2 , 9 9}$ & $151.000 .000,00$ & $\mathbf{2 9 9 . 2 2 9 . 5 1 2 , 9 9}$ \\
\hline JUL & $\mathbf{1 5 3 . 6 8 7 . 0 3 5 , 6 8}$ & $153.000 .000,00$ & $306.687 .035,68$ \\
\hline AGO & $\mathbf{1 5 8 . 1 4 2 . 7 8 5 , 0 8}$ & $155.500 .000,00$ & $313.642 .785,08$ \\
\hline SET & $\mathbf{1 6 3 . 1 9 8 . 5 3 7 , 1 2}$ & $168.000 .000,00$ & $331.198 .537,12$ \\
\hline OUT & $\mathbf{1 5 6 . 4 0 0 . 6 4 1 , 1 4}$ & $169.500 .000,00$ & $325.900 .641,14$ \\
\hline NOV & $\mathbf{1 7 6 . 8 1 3 . 4 8 6 , 3 6}$ & $183.500 .000,00$ & $360.313 .486,36$ \\
\hline DEZ & $\mathbf{3 2 8 . 6 0 1 . 0 9 0 , 0 8}$ & $164.400 .000,00$ & $\mathbf{4 9 3 . 0 0 1 . 0 9 0 , 0 8}$ \\
\hline & & & $\mathbf{4 . 0 0 5 . 1 7 5 . 7 5 1 , 7 4}$ \\
\hline TOTAL & $\mathbf{2 . 0 5 1 . 7 0 2 . 5 1 1 , 4 5}$ & $\mathbf{1 . 9 5 6 . 4 7 3 . 2 4 0 , 2 9}$ & \\
\hline & Fonte:FNDE/DIROF & & \\
\hline
\end{tabular}

No exercício de 2004, houve um grande esforço do FNDE para aumentar a fiscalização nas empresas. Nesse sentido foram escolhidas as 300 maiores empresas com maior potencial de contribuição as quais sofreram visitação dos técnicos do FNDE. Tal iniciativa teve como objetivo, não só a fiscalização em si, mas também aumentar a presença da Autarquia perante àquelas empresas. Outro fator importante que aconteceu foi a edição do Decreto $n^{\circ} 4.943 / 2003$, que fez com as empresas com folha de pagamento a partir de $\mathrm{R} \$$ 2.400.000,00 passassem a arrecadar diretamente no FNDE. Esses fatores contribuíram para aumentar a arrecadação em 2004, além do aumento da massa salarial que ficou em torno de 
9\%, contra um crescimento real da ordem de 15\% na arrecadação do Salário-Educação. Veja os dados na tabela 05 .

TABELA 5

ARRECADAÇÃO BRUTA DO SALÁRIO-EDUCAÇÃO NO ANO DE 2004

\begin{tabular}{|c|c|c|c|}
\hline \multicolumn{4}{|c|}{ ARRECADAÇÃO } \\
\hline MÊS & DIRETA & ARRECADAÇÃO & TOTAL DA \\
\hline & PELO FNDE & PELO INSS & ARRECADAÇÃO \\
\hline JAN & 187.497.457,09 & 318.695.776,04 & 506.193.233,13 \\
\hline FEV & 177.426.095,22 & 148.939.960,92 & 326.366.056,14 \\
\hline MAR & 187.302.932,81 & 186.330.710,17 & 373.633.642,98 \\
\hline ABR & $190.315 .397,29$ & 178.444.730,59 & 368.760.127,88 \\
\hline MAI & 175.714.834,06 & 169.856.217,48 & $345.571 .051,54$ \\
\hline JUN & $180.889 .922,12$ & 181.519.074,91 & 362.408.997,03 \\
\hline JUL & $186.719 .672,68$ & 183.626.994,97 & $370.346 .667,65$ \\
\hline AGO & $182.372 .001,23$ & 193.767.319,25 & 376.139.320,48 \\
\hline SET & 204.044.296,51 & $174.164 .310,50$ & 378.208.607,01 \\
\hline OUT & 195.374.670,48 & 266.984.753,54 & 462.359.424,02 \\
\hline NOV & $180.786 .744,88$ & 198.446.582,25 & 379.233.327,13 \\
\hline DEZ & 364.343.851,02 & $217.697 .848,04$ & $582.041 .699,06$ \\
\hline TOTAL & 2.412.787.875,39 & 2.418.474.278,66 & $4.249 .220 .454,99$ \\
\hline
\end{tabular}


No exercício de 2005, estamos apresentando uma amostragem parcial, ou seja, até setembro de 2005, pois todo nosso enfoque de pesquisa foi até novembro de 2005, com dados fechados disponíveis em sistema até setembro. Neste exercício houve uma ligeira melhora de arrecadação (11,76\%) 1,95\%/mês, no tocante ao comparativo INSS/FNDE. - Conforme Tabela 6

TABELA 6

ARRECADAÇÃO BRUTA DO SALÁRIO-EDUCAÇÃO NO ANO DE 2005 ATÉ SETEMBRO- PEQUENA EVOLUÇÃO NA ARRECADAÇÃO VIA INSS

\begin{tabular}{|c|c|c|c|}
\hline \multicolumn{3}{|c|}{ ARRECADAÇÃO } & \multirow{3}{*}{$\begin{array}{c}\text { TOTAL DA } \\
\text { ARRECADAÇÃO }\end{array}$} \\
\hline MÊS & DIRETA & ARRECADAÇÃO & \\
\hline & PELO FNDE & PELO INSS & \\
\hline JAN & 203.120.852,29 & 316.308.793,02 & 519.429.645,31 \\
\hline FEV & 207.972.178,45 & 389.139.061,98 & 597.111.240,43 \\
\hline MAR & 203.545.259,61 & 234.978.224,61 & 438.523.484,22 \\
\hline ABR & 201.225.548,74 & 206.928.249,16 & 408.153.797,90 \\
\hline MAI & $194.509 .884,43$ & $200.778,444,48$ & 395.288.328,91 \\
\hline JUN & 213.476.430,14 & 129.682.529,97 & 343.158.960,11 \\
\hline JUL & 321.258.405,98 & 261.312.054,25 & $582.570 .460,23$ \\
\hline AGO & 182.660.151,37 & 268.543.651,15 & 451.203.802,52 \\
\hline SET & 211.085.176,10 & 272.658.187,03 & 483.743.363,13 \\
\hline OUT & & & \\
\hline NOV & & & \\
\hline DEZ & & & \\
\hline TOTAL & $1.938 .853 .887,13$ & $2.280 .329 .195,65$ & $4.219 .183 .082,76$ \\
\hline
\end{tabular}


Nas Tabelas 7 a 12 - ANEXOS EXTRAS - Distribuição das quotas estaduais e municipais do Salário-Educação por Unidades da Federação de 2000 a setembro de 2005, sendo quota estadual até 2003 e estadual e municipal a partir de 2004.

TABELA 7 - DISTRIBUIÇÃO DA QUOTA ESTADUAL DO SALÁRIOEDUCAÇÃO FNDE/INSS - 2000

TABELA 8 - DISTRIBUIÇÃO DA QUOTA ESTADUAL DO SALÁRIOEDUCAÇÃO FNDE/INSS - 2001

TABELA 9 - DISTRIBUIÇÃO DA QUOTA ESTADUAL DO SALÁRIOEDUCAÇÃO FNDE/INSS - 2002

TABELA 10 - DISTRIBUIÇÃO DA QUOTA ESTADUAL DO SALÁRIOEDUCAÇÃO FNDE/INSS - 2003

TABELA 11 - DISTRIBUIÇÃO DAS QUOTAS ESTADUAL E MUNICIPAL DO SALÁRIO-EDUCAÇÃO FNDE/INSS - 2004

TABELA 12 - DISTRIBUIÇÃO DAS QUOTAS ESTADUAL E MUNICIPAL DO SALÁRIO-EDUCAÇÃO FNDE/INSS - 2005 ATÉ SETEMBRO.

A evolução da arrecadação bruta do Salário-Educação, no período de 2000 a 2004, teve a seguinte evolução. Veja o Gráfico 1.

Gráfico 1 - Evolução Histórica da Arrecadação Bruta do Salário-Educação - 2000 a 2004

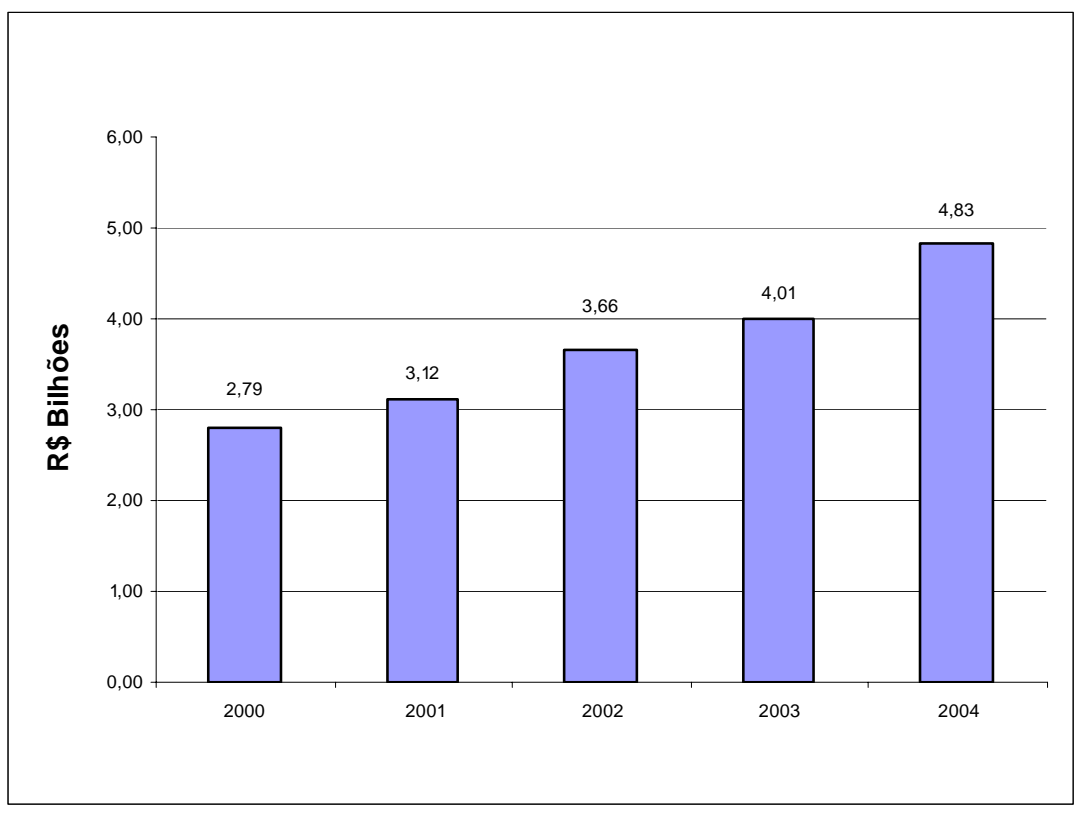

Fonte: FNDE/DIFIN/CGACI 
A arrecadação realizada diretamente pelo FNDE teve a seguinte evolução no período de 2000 a 2004. Veja gráfico 2.

Gráfico 2 - Evolução Histórica da Arrecadação Direta do Salário-Educação pelo FNDE - 2000 a 2004

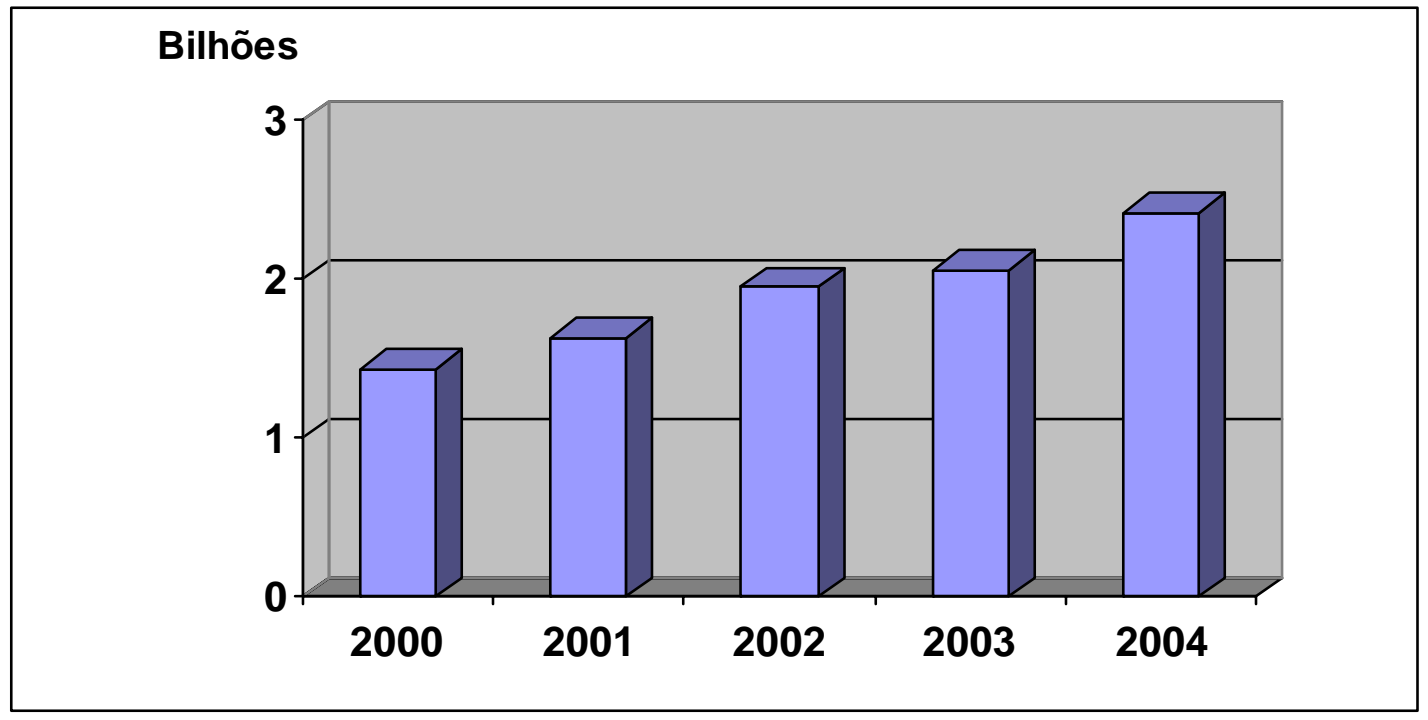

Fonte: FNDE/DIFIN/CGACI

- Inspeções Realizadas Programa Integrado de Inspeção em Empresas e Escolas - PROINSPE, no período de 2000 a 2004.

A realização das inspeções pelo PROINSPE envolve a participação dos funcionários do próprio Programa, de alguns funcionários das Secretarias Estaduais de Educação, além de funcionários das representações do Ministério da Educação, que integram às inspeções nas empresas e escolas previamente selecionadas, nas quais analisam a documentação pertinente, observando a regularidade dos valores recolhidos e adequação das deduções efetuadas, relativas aos alunos participantes do SME.

No ano de 2000, o número de empresas e escolas inspecionadas representou, respectivamente, $8,5 \%$ e $16 \%$ dos totais participantes do SME, resultando na glosa de 2.027 alunos, decorrentes de irregularidades detectadas em escolas, e 273 notificações resultantes de irregularidades encontras nas empresas.

Em 2001, o quantitativo de empresas e escolas inspecionadas representou, respectivamente 9,98\% e 29,03\%, dos totais de participantes do SME, tendo resultado na glosa de 1.206, alunos referentes a irregularidades detectadas em escolas e 157 notificações resultantes de irregularidades em empresas. 
No exercício de 2002, o quantitativo de empresas e escolas inspecionadas representou, 8,86\% e 30,63\% dos totais participantes do SME, resultando na glosa de 732 alunos e 362 notificações a empresas com irregularidades.

Em 2003, o resultado das inspeções somou-se 586 notificações à empresas irregulares representando um total de 10\% das empresas optantes pelo SME e 295 alunos glosados do SME, por irregularidades.

Em 2004, 530 empresas foram fiscalizadas, constatando-se débito no valor R\$ 91,6 milhões, nas empresas com maiores folhas de pagamentos, ou seja, aquelas cujas folhas de pagamento de salários tem valor mínimo de R 2.4 milhões.

A evolução do crescimento da fiscalização, no período de 2000 a 2004 está representada no gráfico 3, de acordo com dados dos Relatórios de Atividades do FNDE do período de 2000 a 2004.

\section{Gráfico 3 - Evolução Percentual das Fiscalizações realizadas pelo PROINSPE - 2000 a 2004}

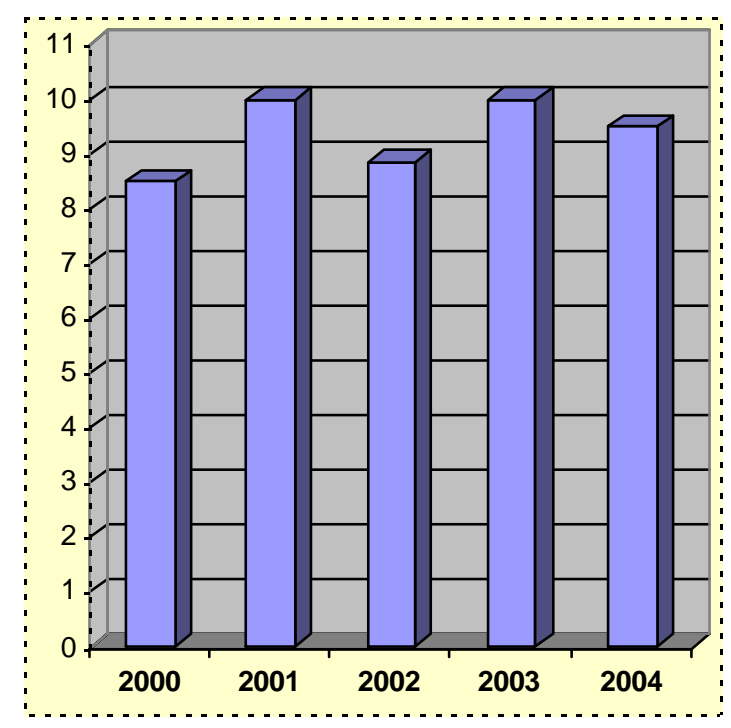

Fonte: FNDE/DIFIN/CGACI

\section{- Parcelamento de Débito}

O parcelamento de débito firmado, em 2000, alcançou um montante de $\mathrm{R} \$ 17,8$ milhões, representando 35,31\% do estoque de parcelamento concedido às empresas, sendo que os outros $64,69 \%$ do total de parcelamento concedidos foram rescindidos e encaminhados 
à Procuradoria Jurídica para realização de cobrança judicial do débito, por inadimplência das empresas.

Em 2001, o parcelamento atingiu o montante de R\$ 20,4 milhões, representando 80,51\% do estoque de dívidas parceladas pelas empresas. Sendo rescindido $19,49 \%$ dos parcelamentos concedidos por inadimplência das empresas.

Em 2002, os recursos oriundos de parcelamentos firmados alcançaram o montante de R\$ 24,42 milhões, representando 88,61\% do total de dívidas parceladas pelas empresas. Do total dos parcelamentos concedidos $11,39 \%$ foram rescindidos por inadimplência das empresas.

Em 2003 foram editadas as Medidas Provisórias n ${ }^{\circ} 3866$ e 75/2003 e as Leis $n^{0}$ 10.673 e 10.684/2003, referentes aos parcelamentos especiais. Possibilitando que $83,17 \%$ dos parcelamentos concedidos fossem liquidados e apenas 16,83\% dos parcelamentos concedidos fossem rescindidos e encaminhados para cobrança judicial.

Em 2004, foram concedidos parcelamentos especiais a 8.769 empresas somando um montante de $\mathrm{R} \$$ 54.600.760,00 arrecadados contra $\mathrm{R} \$$ 55.229.062,00 devidos. Veja Gráfico 4.

Gráfico 4 - Evolução Percentual do Parcelamento no período de 2000 a 2004

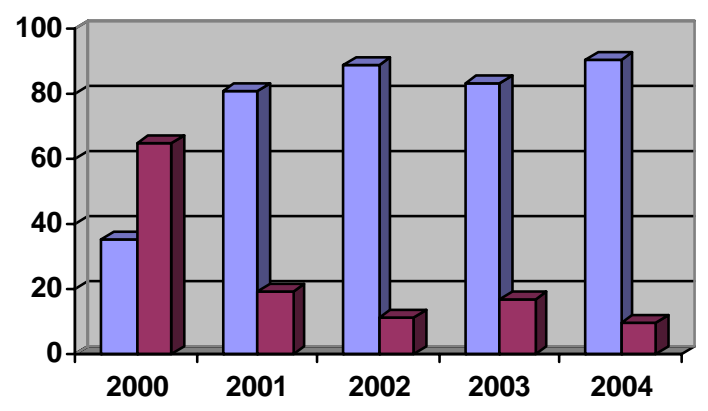




\section{CAPÍTULO - 4 ANÁLISE DA ARRECADAÇÃO DIRETA DA CONTRIBUIÇÃO SOCIAL DO SALÁRIO-EDUCAÇÃO, PELO FNDE}

\subsection{Introdução}

Este capítulo foi desenvolvido com base nos dados obtidos nas entrevistas realizadas com os chefes dos setores: de Apuração e Cobrança de Débito; de Parcelamento de débito; de Arrecadação; de Cadastro; e pela Divisão de Inspeção e Divisão de Análise de Defesa. Nas entrevistas, procurou saber quais eram as dificuldades enfrentadas na realização das atividades que conseqüentemente tornava o setor ineficiente e eficaz. O resultado das entrevistas está sintetizado a seguir, relacionando-se os aspectos positivos e negativos.

\begin{tabular}{|l|}
\hline Aspectos Positivos do FNDE na Arrecadação Direta do Salário-Educação \\
\hline 1. Ausência de registro de corrupção por parte dos técnicos atuantes na área; \\
2. Esforços contínuos de melhoria da arrecadação; \\
3. Tentativas de superação dos setores por meio de novos mecanismos; \\
4. Grandes esforços para se fiscalizar as maiores empresas contribuintes. \\
5. Aumento da arrecadação em 2004 , superior ao crescimento da massa salarial; \\
6. Controle efetivo dos valores recolhidos pelas empresas diretamente no FNDE. \\
7. Com o advento do Decreto n. ${ }^{\text {o }} 4.943$, de 30 de dezembro de 2003 em seu Art. $1 .^{\text {o }}$ \\
inciso II alíneas a) e b) , dá exclusividade de arrecadação para o FNDE, ou seja: as \\
empresas conveniadas até o ano-calendário 2003 , continuam independente de valor \\
de base de contribuição e as empresas cujas bases são igual ou superior a R\$ \\
2.400.000,00, são de exclusividade para recolhimento em arrecadação direta do \\
FNDE.
\end{tabular}

\section{Aspectos Negativos do FNDE na Arrecadação Direta do Salário-Educação}

1. Falta de estrutura adequada;

2. Insuficiência de recursos humanos;

3. Falta de treinamento específico;

4. Falta de carreira própria;

5. Baixos salários dos servidores terceirizados; 

6. Falta de motivação;
7. Ausência de rotinas de trabalho;
8. Mudanças constantes nos cargos de direção;
9. Falta de mecanismos e logística adequados;

10. Dificuldade para mensurar a quantidade de trabalho existente;

11. Ausência de Relatórios setoriais

12. Sistemas informatizados não atende de forma adequada;

13. Mudanças constantes na legislação;

14. Falta de alimentação do Sistema de Cobrança;

15. O Sistema de Cadastro das empresas está desatualizado;

16. Deficiência nos processos de trabalho;

17. Baixo índice de empresas fiscalizadas;

18. Falta de apoio jurídico;

19. Falta de apoio técnico;

20. Falta de integração dos setores;

21. Falta conhecimento sobre quem são realmente os contribuintes diretos;

22. Falta de uma Certidão Negativa para proteger o Salário-Educação;

23. Falta de um campo próprio na Guia (do INSS) para arrecadação do SalárioEducação;

24. Apesar de existir um relatório de acompanhamento de arrecadação constando ausência de recolhimento de empresas optantes, o FNDE não envia comunicação de cobrança a essas empresas;

25. Centralização da arrecadação direta apenas no Banco do Brasil, gerando dificuldade para as empresas;

26. Não se sabe se todas as empresas que deveriam recolher a contribuição diretamente no FNDE se de fato recolhem.

27. Falta de acompanhamento da arrecadação via INSS, não existe prestação por parte do INSS. Muitas vezes as transferências arrecadadas foram repassadas por rateios ou estimativas e não o efetivamente arrecadado. Os parcelamentos via REFIS, incluindo o Salário-Educação, não se tem o montante, ou mesmo estimativa desses financiamentos. O INSS não informa e o FNDE, fica apático da situação.

Além dos aspectos apontados pelos chefes de setores da arrecadação direta do Salário-Educação, foram realizadas entrevistas com o Diretor Financeiro do FNDE, aos quais 
foram feitas as perguntas relacionadas no roteiro para entrevistas constantes dos anexos deste trabalho, apresentado ao nosso colaborador Patrício Barroso Pais, que com seu pleno consentimento e com anuência dos entrevistados, aqui ratificamos. Veja a seguir o pensamento dos dirigentes do FNDE a respeito da arrecadação da contribuição do SalárioEducação.

Pensamento do Diretor Financeiro do FNDE sobre a arrecadação do SalárioEducação, também aponta a questão estrutural como o maior problema. Apesar da quantidade de empresas que recolhem hoje no FNDE ser infinitamente inferior em relação às que recolhem no INSS representa de 50 e 51\% da receita do Salário-Educação.

O FNDE não tem uma estrutura como os outros órgãos responsáveis pela arrecadação de contribuições previdenciária e outras contribuições federais e os próprios impostos que disponibilizam pessoal com carreira própria, com formação específica, tanto em quantidade como em qualidade. Ao contrário o FNDE tem um quadro de funcionários reduzido, com a maior parte terceirizada. As dificuldades que hoje se enfrenta é com relação a orçamento, e os próprios quadros de informática são coisas que tem contribuído para que o FNDE não alcance o nível de eficiência e eficácia que se deseja.

No ano passado pensou-se numa nova parceria com relação a fiscalização e arrecadação do Salário-Educação com órgão como a CEF que ficaria responsável pela arrecadação e o Ministério do trabalho responsável pela fiscalização. Nesse sentido se verificou que existe uma diferença grande entre o aquilo que estima arrecadar e aquilo que efetivamente arrecada. Isso se dá em função da estrutura existente e da falta de condições para apurar as informações para que faça a fiscalização e cobrança eficiente e eficaz.

Com relação a arrecadação feita pelo INSS também, tinha problema por conta da falta de informação, o que ele arrecadava não nos dizia de que arrecadava que natureza de receita era aquela e os valores eram repassados por um índice de rateio em função da alteração da Guia que definia a forma de recolhimento desse tributo.

Existe uma preocupação para saber qual é o nosso potencial, a partir desse potencial tem que se trabalhar uma estratégia de centralização dessa receita no INSS, logicamente, com condições mais favoráveis onde se possa participar mais e conhecer melhor o processo, no qual acredita-se que não adiante manter a arrecadação no FNDE porque não existe condição de fiscalizar e fazer o batimento dos dados adequadamente. É preciso que tenha uma força de trabalho específica, treinada e capacitada e com salário compatível para que possa desenvolver esse tipo de atividade. 
Uma das principais preocupações é com relação às empresas inadimplentes com o Salário-Educação. Não existe uma certidão negativa que proteja o Salário-Educação. Não se sabe se o INSS quando expede aquele CND, se considera as contribuições devidas ao SalárioEducação. Eles dizem que sim, mas analisando o arcabouço legal, não têm entrada para essa questão, se estão fazendo, estão por conta própria, no futuro isso pode ser questionado.

O que o FNDE está tentando fazer para melhorar a arrecadação é no sentido de centralizar a arrecadação e em relação a legislação é preciso criar uma condições para que realmente o salário-educação fique protegido por uma certidão. É preciso também, ter maior acesso as informações que o INSS dispõe com relação ao Salário-Educação e ter uma gerência maior sobre o pagamento daquela parcela de $1 \%$ repassado ao INSS a título de reposição de custos do processo de arrecadação indireta.

Com relação a visão futura da arrecadação do Salário-Educação, em primeiro lugar é preciso conhecer quem são os contribuintes pois não se sabe se as empresas que tem que recolher no FNDE, de acordo com o Decreto, se de fato estão recolhendo.

O FNDE precisa sair do processo operacional, de fiscalização e arrecadação e passar simplesmente a fazer a gestão, ou seja, o acompanhamento da evolução da arrecadação. Tem que ter pleno acesso, e conhecimento sobre quem são os contribuintes e a partir daí ter disponíveis as informações para que possa avaliar o processo e projetar com relação ao futuro daquilo que cabe realmente ao Salário-Educação.

Em segundo lugar, é preciso expandir o Salário-Educação para o ensino médio, porque hoje existe uma preocupação muito grande com esse nível de educação. Na última década houve muito investimento no ensino fundamental, mas, agora existe uma grande demanda em relação ao ensino médio. Todas providências que vêm sendo adotadas e todas as ações que vêm sendo implementadas são no sentido de melhorar a arrecadação para expandir isso aos outros níveis de ensino.

[ A visão que eu tenho é essa é arrecadação centralizada lá no INSS, que conheça quem são os contribuintes que a faça uma cobrança eficiente e que realmente consiga arrecadar mais para prover o FNDE e ao MEC com recursos necessários para o financiamento desses programas sociais que tem uma demanda grande por recursos, e é esse o nosso papel]. 


\section{CONCLUSÃO}

Este capítulo apresentou a análise dos dados levantados nas entrevistas e a partir da interpretação dos fatos foram relacionados os aspectos que os chefes dos setores que compõem a arrecadação do Salário-Educação acham que atrapalham o bom desenvolvimento da arrecadação direta da contribuição social do salário-educação. Analisamos também, as entrevistas realizadas com o Diretor Financeiro, o qual aponta fatos que, juntamente com os dados das entrevistas dos Chefes de setores possibilitaram concluir que os objetivos geral e específicos deste trabalho foram alcançados e estão relacionados na conclusão geral. Onde enfocamos aqui a questão da transparência em relação ao acompanhamento da arrecadação indireta via INSS, onde simplesmente aceitamos o que nos é repassado, não existem acompanhamentos de qualquer tipo de entrada de caixa, não só de arrecadação normal mas de passivos, tais como parcelamentos via REFIS, conversão em renda por depósitos judiciais, receitas transferidos a outros terceiros por códigos errados e que exigiram a RDE Retificação de Dados do Empregador que corrige as distorções, mas não é acompanhado o repatriamento do crédito, é em termos informáticos, mas não em termos de caixa.

Em relação ao objetivo geral deste trabalho, ou seja, verificar a eficiência e a eficácia do FNDE na arrecadação direta da contribuição Social do Salário-Educação, de acordo com os conceitos de eficiência e eficácia utilizados, concluiu-se que este não é eficiente e eficaz, pois não consegue realizar a arrecadação sem perdas e desperdícios, havendo margem para um acréscimo na arrecadação em torno de R 3,2 bilhões, apontados com base nos dados de outras contribuições que utilizam a mesma base.

Com relação aos objetivos específicos, no que tange aos mecanismos de arrecadação adotados pelo FNDE, verificou-se a ausência de mecanismos adequados, bem como a falta de recursos humanos suficientes e treinados além de uma logística capaz de atender as necessidades para uma arrecadação eficiente e eficaz. Os incentivos adversos foram identificados e estão relacionados no quadro de aspectos negativos, de acordo com dados das entrevistas. Verificou-se, ainda, que o FNDE não tem estrutura organizacional adequada para alcançar uma Arrecadação eficiente e eficaz. Com relação arrecadação potencial, a entrevista realizada com o presidente do FNDE aponta o potencial de aproximadamente R\$ 8 bilhões de reais, enquanto que a maior arrecadação bruta realizada foi em 2004 no valor de 4,8 bilhões, sendo R\$ 2,4 bilhões realizada diretamente no FNDE e R\$ 2,4 bilhões pelo INSS, portanto, 
existe um hiato na arrecadação do Salário-Educação da ordem R\$ 3, 2 bilhões, a ser alcançada pelos gestores desta contribuição social.

Verificou-se também que o fato do FNDE não possuir carreira própria como os outros órgãos arrecadadores, contribui para uma queda na qualidade dos trabalhos realizados pela Autarquia, a qual não dispõe de funcionários em quantidade e com a qualidade necessária para a realização da fiscalização e arrecadação do Salário-Educação.

As entrevistas apontaram dados que sugerem a necessidade de realização de investigação sobre a arrecadação indireta, realizada pelo INSS, em virtude da falta de transparência, e desconhecimento do FNDE dos mecanismos adotados. 


\section{CONSIDERAÇÕES FINAIS}

Uma coisa que impressionou na realização desse trabalho, mais especificamente no estudo de casos, foi à conduta ilibada de cada servidor da arrecadação direta da contribuição social do Salário-Educação. Sabe-se que os órgãos que lidam com a arrecadação de impostos estão bastante vulneráveis à corrupção. A prova disso são os noticiários constantes sobre fraudes que acontecem em diversos órgãos públicos em várias partes do país. No entanto, não existe nenhum caso registrado de corrupção na história da arrecadação direta do SalárioEducação. Muito embora, os técnicos que atuam nesta área não tenham um plano de carreira compatível com o seu desenvolvimento e responsabilidade nas ações, como existe na Receita Federal, no INSS e nas Agências. Soma-se a isto a defasagem dos salários dos servidores públicos que não tem carreira específica e ainda, o fato do FNDE ter nas unidades da arrecadação direta em torno de $60 \%$ de servidores terceirizados, sendo a maioria com nível médio de ensino, e ganham menos de R\$1.000,00 por mês.

Embora o quadro acima seja gritante, para uma área tão importante como essa do FNDE com um potencial tão grande de arrecadação, todos os técnicos, atuam com a maior responsabilidade possível exercendo funções que estão muito além daquelas para as quais foram contratadas. Os erros que ocorrem estão relacionados à falta de estrutura em todos os níveis, falta de logística adequada e falta de treinamento para atuação em setores tão específicos, onde são exigidos conhecimentos profundos de legislação entre outros, e principalmente muita responsabilidade e uma profunda vocação ética. Por isso, apesar do FNDE não ser eficiente e eficaz na arrecadação direta da contribuição social do SalárioEducação, os técnicos estão de parabéns pelos esforços ali empenhados. 


\section{RECOMENDAÇÕES}

Com base nos dados levantados nesta análise que configuraram a ineficiência e ineficácia do FNDE, na arrecadação direta da contribuição social do Salário-Educação devido a falta de estrutura adequada, tanto do ponto de vista de recursos humanos, espaço físico e processo de trabalho e, ainda, considerando o fim do SME que se deu em 2003, não existe razão para permanecer dois órgão diferentes arrecadando a mesma contribuição. Além disso, acredita-se que o INSS possui estrutura capaz de realizar a arrecadação total da referida contribuição com maior eficiência, devido a sua vocação arrecadadora de diversos tributos e contribuições, e o fato de possuir carreira própria de fiscal para tal. Portanto, recomenda-se, a realização de estudos sobre a viabilidade de se passar a arrecadação, hoje realizada pelo FNDE, para o INSS, ficando aquela entidade responsável pela arrecadação total do SalárioEducação.

Ressalta-se que tal mudança deverá ser estudada detalhadamente para que se faça um contrato ou convênio com cláusulas bem definidas onde o FNDE possa fazer o acompanhamento e o controle dessa arrecadação, para não correr o risco de se perder esses recursos que são tão importantes para o ensino público fundamental do país.

Acredita-se que essa mudança possa elevar a arrecadação da contribuição social do Salário-Educação, de um patamar de R 4,8 bilhões para no mínimo R 8 bilhões de reais, baseando-se apenas na elevação do Fundo de Garantia por Tempo de Serviço, dos últimos anos o qual é realizado sobre a folha de pagamento dos salários dos empregados, assim como o Salário-Educação.

Tomar uma decisão responsável sobre a arrecadação do Salário-Educação deve ser urgente, pois além do fato de constatar perdas e desperdícios na atual forma de arrecadar deve-se considerar que a economia do país está em plena ascensão, com um crescimento considerável no nível de emprego fato este que elevará o potencial de arrecadação nos próximos anos. Se nenhuma atitude for tomada pelo FNDE, as perdas e prejuízos serão muito grandes, pois com a estrutura hoje existente no FNDE, não é possível aumentar a eficiência e a eficácia da arrecadação.

Além das recomendações anteriores, outro estudo interessante a ser realizado é em

relação as variáveis de previsão da capacidade tributária, com base em modelos que possibilite a medição de um índice de esforço de arrecadação para a contribuição social do Salário-Educação. 
No entanto, com o advento da MP 258 de 21/07/2005, tudo se modificou, com a criação da Receita Federal do Brasil, já apelidada de “super receita” fundindo a receita previdenciária com a receita federal, ficando os terceiros dentro desta super arrecadação e o FNDE de forma conveniada, ficando aí a mesma incógnita e a mesma indagação, como vai ser o acompanhamento de caixa que já era difícil via INSS em uma dimensão muito maior na “SUPER RECEITA” . Não temos dúvidas da eficácia, experiência, estrutura logística do Ministério da Fazenda e de seus Órgãos colegiados, reforçados com esta Receita Federal do Brasil, que ao nosso ver reforça também o já famoso SUPERAVIT PRIMÁRIO, mas deixa no ar a nossa dúvida: VAI HAVER ACOMPANHAMENTO DE INGRESSOS NO CAIXA E ESTE INGRESSO SERÁ MOSTRADO SEU DESTINO, OU FARÁ PARTE DE GRANDE BOLO VISANDO SUPERAVIT PRIMÁRIO. Ficando assim nossa interrogação?

A MP 258/2005, foi aprovada na Câmara dos Deputados e rejeitada no Senado por falta de quorum, no dia 18/11/2005, prazo final para votação, extinguindo assim a Super Receita, voltando tudo ao status quo, ficando a expectativa de um futuro projeto de lei para criação da almejada RFB - Receita Federal do Brasil.

Se nada der certo, temos como perspectivas um provável melhoramento na eficácia de arrecadação via FNDE, o que não é ferino nem vitriólico, já fortalecido pelo Decreto 4943/2003, citado no quadro de vantagens. É que com a descentralização da quota estadual do Salário-Educação em estadual e municipal regulamentado pela Lei 10.832 de 29/12/2003, teríamos um maior apoio logístico de arrecadação de maneira indireta. Como há interesse no aumento da arrecadação tanto por parte do FNDE, como pelos estados e municípios, ainda mais com a extensão não só para o ensino fundamental, mas também para a educação infantil e ensino médio, teríamos de maneira indireta um aumento de nossas estruturas (um dos nossos principais problemas quanto à eficácia) que poderá ser feito por meio de convênios entre estados e municípios, em microrregiões, inclusive a busca de apoio com associações de municípios dentro do estado, com acompanhamento e treinamento pelo FNDE, incrementando assim uma maior eficácia de arrecadação. Ademais, devido a experiência de vivência (apesar do número reduzido de servidores), aparato cibernético em termos de controles local ( alguns já em nível nacional), que poderá ser disponibilizado em rede nacional nos pontos de apoio. Devemos manter o INSS como parceiro na arrecadação, mas o controle deve ser do FNDE e as conquistas alcançadas em termos de exclusividade de arrecadação deve ser mantido a favor do FNDE; como já disse, meios e pessoal capacitado o FNDE tem, sua estrutura e apoio logístico fora do DF é que são pequenos, se aumentarmos, sem 
dúvida, teremos uma maior eficácia na arrecadação, não só em termos de alcance dos objetivos (inclusive investimentos na expansão do ensino), mas um significante aumento dos valores arrecadados. 


\section{REFERÊNCIAS BIBLIOGRÁFICAS}

1. COELHO, Eduardo José Pereira - O papel e o Financiamento Público das Instituições de Ensino Superior Particulares, Educação Brasileira, $n_{-}^{o} 18,1_{-}^{o}$ semestre, Brasília, 1987.

2. CUNHA, Luiz Antonio - Escola Particular x Escola Pública. ANDE - Revista da Associação Nacional de Educação, n_- $n_{-}^{\circ}$ SP, 1981.

3

- Verbas públicas para Universidades Públicas, ANDE - Revista da Associação Nacional de Educação n_7, SP, 1984.

4. - Verbas públicas para Universidades Públicas, ANDE - Revista da Associação Nacional de Educação, n_o, SP, 1984.

5.

- Os limites da Escola Particular na Democratização do Ensino, in:

Simpósios - III CBE, Ed. Loyola, SP, 1984.

6. - (coord.) Escola Pública, Escola Particular e a democratização do ensino, Cortez, SP, 1985.

7. - A Educação nas Constituintes Brasileiras: Análise e Propostas (texto elaborado a partir da participação do autor nos debates desenvolvidos sobre o tema no Sindicato de Professores do Município do RJ, set./85; na Faculdade de Educação da USP; na série "UFF debate Brasil Constituinte" e Ciência ás seis e meia, da Regional Rio da SBPC, out./85.

8. - A Educação na Nova Constituição - IV CBE, Goiânia, 02 a 05 de setembro de 1986.

9. - Educação na transição para a democracia: o caso do Brasil, Educação e Realidade, Vol. 13, $n_{-}^{o}$ 2, Porto Alegre, julho-dezembro de 1988.

10. - Educação na transição para a democracia: o caso do Brasil, maio de 1988 (mimeo).

11. CUNHA, Luiz Antonio - Quem tem medo do ensino público (estatal)?, Ciência e Cultura, Vol. 40, $n^{\circ}$. 4, abril de 1988. 
12. CURY, Carlos Roberto Jamil e NOGUEIRA, Magna Alice L. C. - O atual discurso dos protagonistas do Ensino Privado, in: Simpósios - III CBE, Ed. Loyola, SP, 1984.

13. DIAS, Eduardo Fernandes - O Parecer Ferraz e o ensino pago, Educação e Sociedade, $n_{-}^{o}$ 12, Campinas. SP, setembro de 1982.

14. FRIGOTTO, Gaudêncio (org.) - Ensino Pago: A Inversão Autoritária, Cadernos CEDES, $n_{-}^{o} .5$, A. D.

15. GOMES, Candido Alberto Gomes - Os quatro anos da Emenda Calmon: Qual o seu impacto?, Revista Brasileira de Estudos Pedagógicos, $n_{-}^{o}$ 162, Brasília, maio-agosto de 1988.

16. JENSEN, Ana Lúcia - A Nova Lei de Diretrizes e Bases da Educação e o Financiamento do Ensino -Financiamento do $\mathbf{l}_{-}^{o}$ grau: Salário-Educação Comunicação apresentada à V Conferência Brasileira de Educação, Brasília, agosto de 1988.

17. MEDEIROS, Marilena Rescala C. de - O Desafio da Educação Pública, Presença, $n_{-}^{o}$ 10, RJ, julho de 1987.

18. MELCHIOR, José Carlos de Araújo - Algumas Políticas Públicas e o Financiamento da Educação na Nova Lei de Diretrizes e Bases da Educação Nacional - texto apresntado à XIV Reunião Anual da ANPAE (Associação Nacional de Profissionais de Administração Escolar), realizada em Beto Horizonte - São Paulo, abril de 1989.

19. MENDES, Armando - Considerações sobre o texto "Os Quatro Anos da Emenda Calmon: Qual o seu Impacto?, Revista Brasileira de Estudos Pedagógicos, $n_{-}^{o}$. 162, Brasília, maioagosto, 1988.

20. NEVES, Lúcia Maria Wanderley — Financiamento da Educação e Constituinte - O Salário Educação e os Programas de Bolsas de Estudo, Fórum Educacional, Vol. 1, $n_{-}^{o} 2$, RJ. abril-junho, 1987.

21. OHLE, Águeda Bernadete - O Estado e a Universidade: a luta pela sobrevivência na escola pública, Educação e Sociedade, $n_{-}^{o}$ 29, Campinas. SP, julho, 1988.

22. República Federativa do Brasil — Constituição 1988, Isto é- Senhor.

23. SAVIANI, Dermeval - Ensino Público e Algumas Falas sobre Universidade, Cortez, 3ed., SP, 1986. 
24. - Política e Educação no Brasil, Ed. Cortez, SP, 1987.

25. SOBRAL, Fernanda A. da Fonseca, PINHEIRO, Maria Francisca Salles e DAL ROSSO, Sadi - Ensino Superior: descompromisso do estado e privatização, Educação e Sociedade, $n_{-}^{o}$ 28, Campinas—SP, dezembro, 1987.

26. UNDIME - União dos Dirigentes Municipais de Educação do Estado de São Paulo Salário-Educação: captação, aplicação e benefícios para o Município, novembro, 1987.

27. VELloso, Jacques - Política Educacional e Recursos para o Ensino: O Salário Educação e a Universidade Federal, Cadernos de Pesquisa, $n_{-}^{\circ}$ 61, São Paulo, maio, 1987. 28. - O Financiamento da Educação na transição democrática, in: Educação e transição Democrática, Cortez, SP, 1987.

29. - Financiamento das políticas públicas: a educação, ANDE - Revista da Associação Nacional de Educação, $n_{-}^{o}$ 12, SP, 1987.

30. - A Nova Lei de Diretrizes e Bases da Educação e o financiamento do ensino: pontos de partida, Educação e Sociedade, $n_{-}^{o}$ 30, SP, agosto, 1988.

31. - Investimento público em educação: quanto e onde?, Ciência e Cultura, Vol. 40, no. 4, abril, 1988.

32. - Os Quatro Anos da Emenda Calmon e seu Impacto: um Comentário, Revista Brasileira de Estudos Pedagógicos $n_{-}^{\circ}$ 162, Brasília, maio-agosto, 1988.

BENSON, Charles. The Economics of Public Education, $2^{\text {a }}$ ed., Houghton Miffin, Boston, 1970.

CAPANEMA, Clélia de Freitas. Experiência: Balanço Social como Critério de Custo Benefício. Revista “Em Aberto” n 74. Brasília, INEP, 2001.

CEPAL (Comissão Econômica para a América Latina e o Caribe) 2003. Rumo ao Objetivo do Milênio de Reduzir a Pobreza. Livros da CEPAL nº 70. 2003.

CEPAL . Pobreza e mercados no Brasil. Uma Análise de Iniciativas de Políticas Públicas. Brasília, 2003. 
Constituição da República Federativa do Brasil, com a Emenda 14/96 - capítulo III - Da Educação, da Cultura e do Desporto.

FACHIN, Odília. Fundamentos de Metodologia. São Paulo. Saraiva, 2003.

FNDE. Relatório de Atividades/2003

MATIAS PEREIRA, J. Finanças Públicas. A Política Orçamentária no Brasil.São Paulo, Atlas, 2003.

MATIAS PEREIRA, J. Reforma do Estado e Transparência: Estratégia de controle da corrupção no Brasil. Apresentado no VII Congresso Internacional Del CLAD sobre la Reforma Del Estado y de la Administración Pública, Lisboa, Portugal, 8-11 oct. 2002.

MEC/FNDE . Legislação Salário-Educação: FNDE/INSS. MEC, 2002.

MERCADANTE, Aloizio e outros. Investimentos em Educação, Ciência e Tecnologia -O que pensam os economistas. Brasília, UNESCO Brasil, Ministério da Educação, Instituto Sangari, 2004.

NOGUEIRA, Cláudio André Gondin et ali. Crescimento e Capital Humano: Evidências Empíricas Recentes para o Brasil numa Perspectiva Regional. Revista de Estudos Econômicos no 14 do Centro de Estudos de Economia Regional, da Universidade Federal do Ceará, 2000.

PINTO, J. M. R. Os recursos para a educação no Brasil no contexto das Finanças Públicas. Brasília. Ed. Plano, 2000.

RIBEIRO, José Aparecido Carlos. Financiamento da Educação nos anos 90. Revista “Em aberto” nº 74. Brasília, INEP, 2001.

Resolução $n^{\circ}$ 2, de 7/12/2001 - dispõe sobre a arrecadação direta do Salário-Educação no FNDE;

Resolução $n^{0}$ 19, de 05/09/2000 - dispõe sobre o Programa Integrado de Inspeção em Empresas e Escolas.

SANDRONI, Paulo (Org). Dicionário de Economia. 2 ed. São Paulo: Best Seller, 1989. 
SCHUlTZ, T. W. O Capital Humano Investimento em Educação e Pesquisa. In: Investimento em Capital Humano. Rio de Janeiro. 1973.

SCHULTZ, T. W. O Valor econômico da Educação. 2 ed. Rio de Janeiro. Zahar, 1973.

TELES, Vladimir Kühl. Capital Humano e Crescimento Econômico: Uma Abordagem

Teórica e Empírica. Tese de Doutorado, apresentada ao Departamento de Economia da Universidade de Brasília, maio de 2004.

VELloso, Jacques. Pesquisas no País sobre o financiamento da Educação: Onde

Estamos?: Disponível na Internet: < http://inep.gov.br/comped/instituições/ampae.htm> Acessado em 11 de novembro de 2004. 


\begin{abstract}
ANEXOS

\section{Entrevistas}

\section{ROTEIRO PARA ENTREVISTA}

Entrevistado:. Antônio Corrêa Neto - Diretor Financeiro do Fundo Nacional de Desenvolvimento da Educação - FNDE
\end{abstract}

1) Quais são as dificuldades estruturais relativas à arrecadação do Salário-Educação?

2) Por quê o FNDE arrecada apenas parte do Salário-Educação?

3) O Sr conhece o potencial da Arrecadação Direta do Salário-Educação?

4) Existe diferença entre arrecadação potencial e a arrecadação efetiva do SalárioEducação?

5) Se existe, por quê?

6) Como o FNDE poderia sanar esse hiato da arrecadação do Salário-Educação?

7) Quais são as providências que o FNDE está adotando para aumentar a arrecadação do Salário-Educação?

8) Considerando a EFICIÊNCIA como sendo a qualidade de fazer com excelência, sem perdas ou desperdícios, o Sr. Considera que o FNDE é eficiente na arrecadação direta do Salário-Educação?

9) Considerando que EFICÁCIA é realizar perfeitamente determinada tarefa ou função, de forma que se produza o resultado pretendido, o que o Sr. Pensa sobre a eficácia do FNDE na arrecadação direta do Salário-Educação?

10) Quais são os incentivos adversos da arrecadação direta do Salário-Educação?

11) Qual a sua visão futura da arrecadação do Salário-Educação?

12) O Sr. Não acha que o FNDE, esta cada vez mais vulnerável com as mudanças no comportamento do Salário-Educação?

13) Como o Sr. Vê o futuro do Salário-Educação, com os parâmetros de mudanças na PEC da reforma tributária em tramitação no Congresso Nacional?

14) Quais são as expectativas do FNDE, quanto a suposta substituição da nomenclatura (Salário-Educação para o IVA)? 
15) O Sr. não acha que as mudanças prevista, trarão prejuízo na composição dos recursos para o financiamento da educação básica?

Brasília-DF, 30 de janeiro de 2009. 